\title{
Click Chemistry in the Design and Production of Hybrid Tracers
}

\author{
Albertus W. Hensbergen, ${ }^{\dagger}$ Danny M. van Willigen, ${ }^{\dagger}$ Mick M. Welling, ${ }^{\dagger}$ (i) Felicia A. van der Wijk, \\ Clarize M. de Korne, ${ }^{\dagger}$ Matthias N. van Oosterom, ${ }^{\dagger}$ Margret Schottelius, ${ }^{+}$Hans-Jürgen Wester, ${ }^{\ddagger}$ \\ Tessa Buckle, ${ }^{\dagger}$ and Fijs W. B. van Leeuwen* ${ }^{\dagger}{ }^{\dagger}$ \\ ${ }^{\dagger}$ Interventional Molecular Imaging Laboratory, Department of Radiology, Leiden University Medical Center, Leiden 2333 ZA, The \\ Netherlands \\ ${ }^{\ddagger}$ Pharmaceutical Radiochemistry, Technische Universität München, Garching 85748, Germany
}

Supporting Information

\begin{abstract}
Hybrid tracers containing both fluorescent and radioactive imaging labels have demonstrated clinical potential during sentinel lymph node procedures. To combine these two labels on a single targeting vector that allows tumor-targeted imaging, end-labeling strategies are often applied. For $\alpha_{\mathrm{v}} \beta_{3}$-integrin-targeting hybrid tracers, providing an excellent model for evaluating tracer development strategies, end-labeling-based synthesis provides a rather cumbersome synthesis strategy. Hence, the aim of this study was to investigate the use of heterobifunctional cyanine dyes in a click-chemistry-based synthesis strategy for RGD-based hybrid tracers. The triazole-based hybrid tracers DTPA.DBCO.N $\mathbf{N}_{3}\left(\mathbf{S O}_{3}\right)-\mathbf{C y 5}-\mathbf{c}[\mathbf{R G D y K}]$ and DTPA.BCN. $\mathbf{N}_{3}\left(\mathrm{SO}_{3}\right)$-Cy5-c[RGDyK] were obtained in fewer steps than DTPA-Lys $\left(\mathrm{Cy}_{5}\left(\mathrm{SO}_{3}\right)\right.$ methyl)-Cys-c[RGDyK] and had partition coefficients of $\log P_{(\mathrm{o} / \mathrm{w})}=-2.55 \pm 0.10,-1.45 \pm 0.03$, and $-2.67 \pm 0.12$, respectively. Both tracers were chemically stable, and the brightnesses of DTPA.DBCO.N ${ }_{3}\left(\mathrm{SO}_{3}\right)-\mathrm{Cy} 5-\mathrm{c}[\mathrm{RGDyK}]$ and DTPA.BCN.N ${ }_{3}\left(\mathrm{SO}_{3}\right)-\mathrm{Cy} 5-\mathrm{c}[\mathrm{RGDyK}]$ were, respectively, $23 \times 10^{3}$ and $40 \times 10^{3} \mathrm{M}^{-1} \mathrm{~cm}^{-1}$; lower than that of the reference tracer DTPA-Lys $\left(\mathbf{C y}^{2}(\mathbf{S O})_{3}\right)$ methyl)Cys-c[RGDyK] $\left(50 \times 10^{3} \mathrm{M}^{-1} \mathrm{~cm}^{-1}\right)$. Assessment of serum protein binding revealed no statistically significant difference $(44 \pm$ 2 and $40 \pm 2 \%$ bound for DTPA.DBCO.N ${ }_{3}\left(\mathrm{SO}_{3}\right)-\mathrm{Cy5}-\mathrm{c}[\mathrm{RGDyK}]$ and DTPA.BCN.N $\mathbf{N}_{3}\left(\mathrm{SO}_{3}\right)-\mathrm{Cy5}$-c [RGDyK], respectively; $36 \pm 5 \%$ bound for DTPA-Lys $\left(\mathbf{C y 5}\left(\mathrm{SO}_{3}\right)\right.$ methyl)-Cys-c $\left.[\mathrm{RGDyK}] ; p>0.05\right)$. DTPA.DBCO.N ${ }_{3}\left(\mathbf{S O}_{3}\right)-\mathrm{Cy}_{5}-\mathrm{c}[\mathrm{RGDyK}]\left(K_{\mathrm{D}}=\right.$ $17.5 \pm 6.0)$ had a statistically significantly higher affinity than the reference compound DTPA-Lys $\left(\mathrm{Cy}^{2}\left(\mathrm{SO}_{3}\right) \mathbf{m e t h y l}\right)$-Cysc[RGDyK] $\left(K_{\mathrm{D}}=30.3 \pm 5.7 ; p<0.0001\right)$, but DTPA.BCN.N ${ }_{3}\left(\mathbf{S O}_{3}\right)$-Cy5-c $[$ RGDyK] had a statistically significantly lower affinity $\left(K_{\mathrm{D}}=76.5 \pm 18.3 \mathrm{nM} ; p<0.0001\right)$. Both $\left[{ }^{111} \mathrm{In}\right]$ DTPA.DBCO.N ${ }_{3}\left(\mathbf{S O}_{3}\right)$-Cy5-c[RGDyK $]$ and [ ${ }^{111}$ In $]$ DTPA.BCN. $\mathbf{N}_{3}\left(\mathrm{SO}_{3}\right)$-Cy5-c[RGDyK] enabled in vivo visualization of the 4T1 tumor via fluorescence and single-photon emission computed tomography (SPECT) imaging. Biodistribution data (\% ID/g) revealed a significant increase in nonspecific uptake in the kidney, liver, and muscle for both $\left[{ }^{111} \mathbf{I n}\right]$ DTPA.DBCO.N ${ }_{3}\left(\mathbf{S O}_{3}\right)$-Cy5-c [RGDyK $]$ and $\left[{ }^{111} \mathbf{I n}\right]$ DTPA.BCN. $\mathbf{N}_{3}\left(\mathrm{SO}_{3}\right)$-Cy5-c[RGDyK]. As a result of the higher background activity, the tumor-to-background ratio of the click-labeled RGD analogues was twofold lower compared to the end-labeled reference compound. The use of click chemistry labeling did not yield a pronounced negative effect on serum protein binding, in vitro stability, and receptor affinity; and tumors could still be visualized using SPECT and fluorescence imaging. However, quantitative in vivo biodistribution data suggest that the triazole and strained cyclooctyne moieties associated with this type of click chemistry negatively influence the pharmacokinetics of RGD peptides. Nevertheless, the design might still hold promise for other targets/ targeting moieties.
\end{abstract}

\section{INTRODUCTION}

Fluorescence has a broad application as a modality for in vitro and in vivo imaging. ${ }^{1,2}$ In the clinical field, an increasing interest
Received: May 21, 2019

Accepted: July 4, 2019

Published: July 22, 2019 
Scheme 1. (A) Schematic Overview of the Original Multifunctional Single-Attachment-Point RGD-based Hybrid Tracer Design (End-Labeling; Left, with the Dye in Blue, Chelate in Red, Targeting Moiety in Green and Linker in White) and New Heterobifunctional RGD-based Hybrid Tracer Wherein the Dye Is Used as Linker (Right, with the Dye in Blue, DTPA in Red, and Targeting Moiety in Green). (B) Chemical Structures of the Reference Compound DTPA-Lys $\left(\mathrm{Cy}_{5}\left(\mathrm{SO}_{3}\right) \mathrm{methyl}^{-\mathrm{Cys}-}\right.$

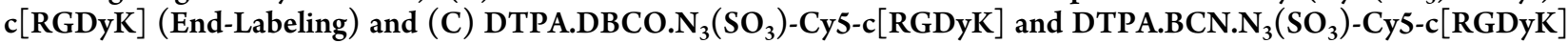
(Modular, Heterobifunctional Design Employing a Cy5 Dye as Spacer between Chelate and Targeting Moiety Using Click Chemistry)
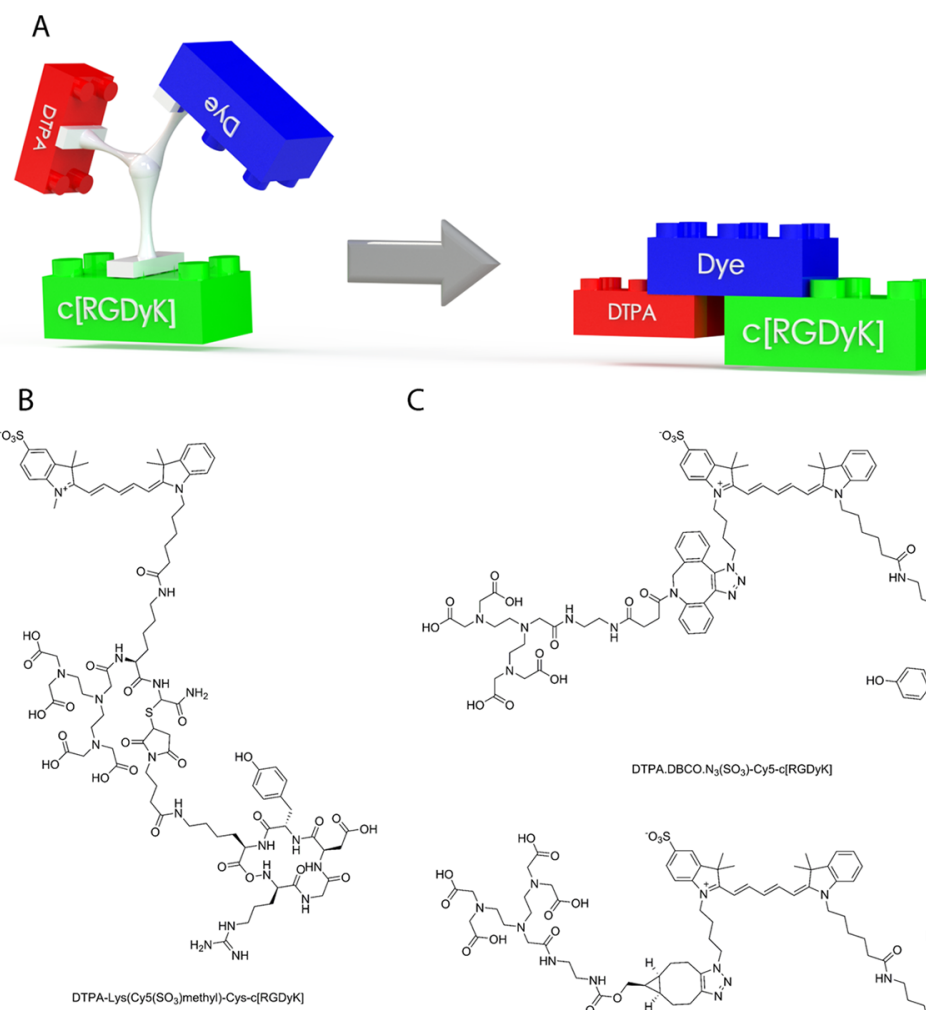

C
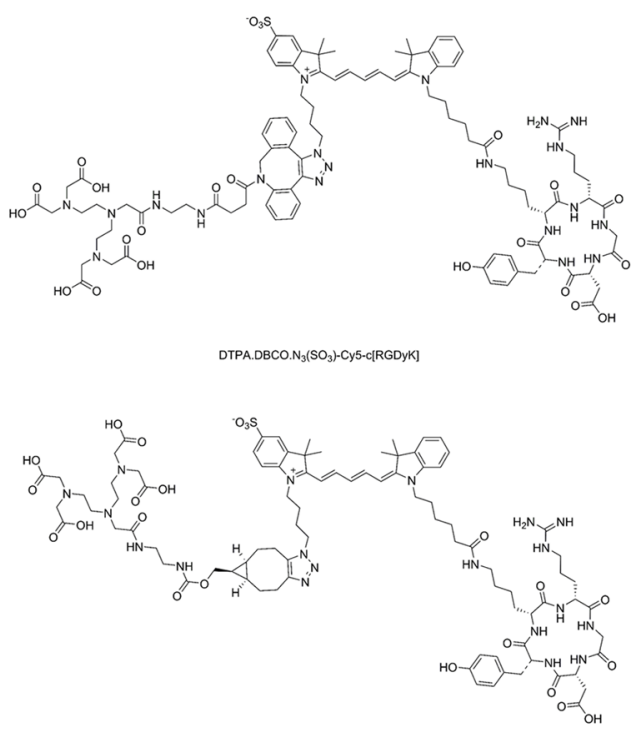

DTPA.BCN.N.N $\left(\mathrm{SO}_{3}\right) \cdot-\mathrm{Cy} 5-$-c[RGDYK $]$

in fluorescence imaging has been triggered by the introduction of fluorescence camera systems that can be applied during surgery. $^{3-5}$ In this context, real-time fluorescence imaging is utilized to visualize a distinct (e.g., diseased) tissue type within the surgical field. The value of fluorescence for surgical guidance is limited by signal attenuation, and therefore the technique only provides accurate guidance in superficial applications $(<1 \mathrm{~cm})$ and does not allow for preoperative imaging. ${ }^{6,7}$ On the other hand, $\gamma$ rays produced by isotopes such as ${ }^{99 \mathrm{~m}} \mathrm{Tc}$ and ${ }^{111} \mathrm{In}$ are not held back by this characteristic and can penetrate human tissue without limitations, which makes them suited for noninvasive (preoperative) imaging. ${ }^{8}$

To combine these features, tracers that contain both a fluorescent and radioactive imaging label can be designed. In these so-called "dual-labeled", "bimodal", or rather "hybrid" tracers, the fluorescent and radioactive signatures complement each other, creating a "best-of-both-worlds" scenario in clinical image-guided surgery applications. ${ }^{8-10}$ Today, hybrid tracers containing cyanine dyes (Scheme $1 \mathrm{~A}$, left) are constructed by conjugating branched linkers (in white) bearing both the radioactive label (in red; mostly a chelate) and the fluorescent dye (in blue) to the targeting vector (in green), i.e., containing end-conjugated dyes as introduced by Josephson et al. ${ }^{11,12}$ In practice, however, such end-conjugated cyanine-dye-based hybrid tracers make use of redundant spacers and suffer from a low synthetic yield due to the larger number of synthetic steps with concomitantly low yields.

As an alternative to end-labeling strategies, we hypothesized that it may be possible to improve the ease of synthesis by using click chemistry, which has been on the rise ever since the investigation of the 1,3-dipolar cycloaddition by Huisgen in the 1960s. After about four decades, Sharpless and Meldal independently discovered the copper-catalyzed click reaction in which 1,4-disubstituted 1,2,3-triazoles were formed from azides and terminal alkynes. The toxicity of copper prompted Sletten and Bertozzi to explore copper-free click chemistry using strain-promoted azide-alkyn cyclocaddition (SPAAC). SPAAC has been of great interest in the field of molecular imaging where radio- and fluorescence-labeling strategies have been independently studied. ${ }^{2,13}$ The required ligands (e.g., dibenzocyclooctyne (DBCO) or bicyclo[6.1.0]nonyne (BCN) groups) are commercially available, and this reaction is one of the most-studied in the field of bioorthogonal chemistry. Despite the fact that click chemistry for in vivo fluorescence imaging has already been applied, ${ }^{14,15}$ the synthesis of click-chemistry-based hybrid tracers is, to date, only described using antibodies and not 
Table 1. Photophysical and Chemical Properties of Fluorophores $\left(\mathrm{H}_{2} \mathrm{~N}\left(\mathrm{SO}_{3}\right)-\mathrm{Cy} 5-\mathrm{COOH}, \mathrm{N}_{3}\left(\mathrm{SO}_{3}\right)-\mathrm{Cy} 5-\mathrm{COOH}\right)$ and $\mathrm{Hybrid}$ Tracers (DTPA-Lys $\left(\mathrm{Cy} 5\left(\mathrm{SO}_{3}\right)\right.$ methyl)-Cys-c [RGDyK], DTPA.DBCO.N $\mathrm{N}_{3}\left(\mathrm{SO}_{3}\right)$-Cy5-c[RGDyK], DTPA.BCN.N $\mathrm{N}_{3}\left(\mathrm{SO}_{3}\right)-\mathrm{Cy} 5-$ $\mathrm{c}[\mathrm{RGDyK}])^{a}$

\begin{tabular}{|c|c|c|c|c|c|c|c|c|}
\hline \multirow[b]{2}{*}{ compound } & \multicolumn{2}{|c|}{$\lambda_{\text {ex }} / \lambda_{\text {em }}($ Stokes shift; nm $)$} & \multicolumn{3}{|c|}{$\begin{array}{c}\text { Molar absorbance } \\
\text { coefficient } \\
\left(\varepsilon ; \cdot 10^{5} \mathrm{M}^{-1} \mathrm{~cm}^{-1}\right)\end{array}$} & \multirow{2}{*}{$\begin{array}{l}\Phi_{\mathrm{F}} \\
(\% \text { in } \\
\text { PBS) }\end{array}$} & \multirow{2}{*}{$\begin{array}{l}\text { Brightness }\left(\times 10^{4}\right. \\
\left.\mathrm{M}^{-1} \mathrm{~cm}^{-1} \text { in PBS }\right)\end{array}$} & \multirow{2}{*}{$\begin{array}{c}\log P_{(\mathrm{o} / \mathrm{w})} \\
\left({ }^{99 \mathrm{~m}} \mathrm{Tc}-\mathrm{labeled} ;\right. \\
\mathrm{n}=6)\end{array}$} \\
\hline & DMSO & $\mathrm{H}_{2} \mathrm{O} / \mathrm{PBS}$ & DMSO & $\mathrm{H}_{2} \mathrm{O}$ & PBS & & & \\
\hline $\mathrm{N}_{3}\left(\mathrm{SO}_{3}\right)-\mathrm{Cy} 5-\mathrm{COOH}^{b}$ & $656 / 676(20)$ & $644 / 662(18)$ & 2.18 & 1.31 & 1.89 & 13 & 2.5 & $d$ \\
\hline methyl- $\left(\mathrm{SO}_{3}\right) \mathrm{Cy} 5-\mathrm{COOH}^{22 b}$ & $653 / 672(19)$ & $642 / 658(16)$ & 2.38 & 1.76 & 2.12 & 13 & 2.8 & $d$ \\
\hline DTPA-Lys $\left(\mathrm{Cy} 5\left(\mathrm{SO}_{3}\right)\right.$ methyl $)-\mathrm{Cys}-\mathrm{c}[\mathrm{RGDyK}]^{c}$ & $654 / 675(21)$ & $644 / 663(19)^{21}$ & $d$ & & $d$ & $19^{21}$ & $5.0^{e}$ & $-2.67 \pm 0.12$ \\
\hline DTPA.DBCO.N ${ }_{3}\left(\mathrm{SO}_{3}\right)-\mathrm{Cy} 5-\mathrm{c}[\mathrm{RGDyK}]$ & $655 / 674(19)$ & $646 / 665(19)$ & $d$ & $d$ & $d$ & 12 & $2.3^{e}$ & $-2.55 \pm 0.10$ \\
\hline DTPA.BCN.N ${ }_{3}\left(\mathrm{SO}_{3}\right)$-Cy5-c[RGDyK] & $645 / 665(20)$ & $655 / 674(19)$ & $d$ & d & d & 21 & $4.0^{e}$ & $-1.45 \pm 0.03$ \\
\hline
\end{tabular}

${ }^{a}$ Note that for the determination of $\log P\left({ }_{\mathrm{o} / \mathrm{w}}\right)$, the following radiolabeled tracers were used: $\left.{ }^{99 \mathrm{~m}} \mathrm{Tc}\right] \mathrm{DTPA}-\mathrm{Lys}\left(\mathrm{Cy} 5\left(\mathrm{SO}_{3}\right)\right.$ methyl)-Cys-

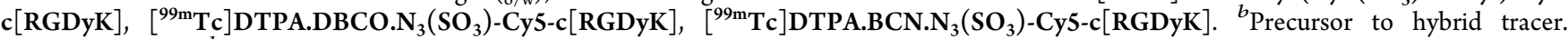
${ }^{c}$ Reference tracer. ${ }^{d}$ Not determined. ${ }^{e}$ Estimated by using the $\varepsilon$ of the free fluorophore.

peptides. ${ }^{16}$ A design wherein the fluorophore also fulfills the role as linker (Scheme 1, right) has, to the best of our knowledge, only been researched using 4,4-difluoro-4-bora-3a,4a-diaza-sindacene (BODIPY) dyes. ${ }^{16}$ Use of a small-molecule, copperfree click-based design incorporating cyanine dyes as a linker has not yet been described.

The aim of this study was therefore to evaluate the use of a click-chemistry-based labeling strategy for peptides to improve the ease of synthesis and synthetic yield of peptide-based hybrid tracers while creating a conjugated tracer with a more compact structure (Scheme 1). To study the influence of chemically introduced alterations in the context of earlier end-conjugated tracer developments (resulting in reference tracer DTPALys (Cy5 ( $\left.\mathrm{SO}_{3}\right)$ methyl)-Cys-c[RGDyK]; ${ }^{17}$ Scheme 1B), the well-known $\alpha_{\mathrm{v}} \beta_{3}$-integrin-targeting RGD peptide (c[RGDyK]) was chosen as the targeting moiety. ${ }^{17-19}$ In the novel tracer design, the heterobifunctional dye functions as a linker that enables the coupling of both a chelator, e.g., diethylenetriaminepentaacetic acid (DTPA), and the targeting vector (resulting in D T PA.D B CO.N ${ }_{3}\left(\mathrm{SO}_{3}\right)-\mathrm{Cy} 5-\mathrm{c}$ [ R G D Y K ] and DTPA.BCN. $\mathbf{N}_{3}\left(\mathbf{S O}_{3}\right)-\mathbf{C y 5}$-c [RGDyK]; Scheme 1C). $\mathrm{DBCO}$ and $\mathrm{BCN}$ were chosen as click handles due to their availability and reaction kinetics $\left(k=310\right.$ and $140 \times 10^{-3} \mathrm{M}^{-1}$ $\mathrm{s}^{-1}$, respectively). As a constant factor in both the end-labeled and click-chemistry-based strategies, the heterobifunctional Cy5 dye was incorporated in the tracer design based on the outcome of previous studies; a tracer's biodistribution can be optimized by shielding the dye from the environment. ${ }^{20}$ Previous studies wherein the fluorescent component of a hybrid tracer was optimized to provide beneficial properties for in vivo use resulted in the selection of $\mathbf{N}_{3}\left(\mathbf{S O}_{3}\right)$-Cy5-COOH. ${ }^{17,21,22}$ As such, the use of this dye was-together with the DTPA molecule and RGD targeting vector-implemented as a constant factor in both the end-labeled (reference) and click-chemistry-based synthesis strategies. The chemical and photophysical properties, along with in vivo biodistribution, of the RGD-based hybrid tracers were analyzed using photophysical analysis and biological evaluation in vitro and in vivo as outlined by the European Association of Nuclear Medicine. ${ }^{23}$

\section{RESULTS AND DISCUSSION}

Chemistry. As a general synthon for all compounds in this study, the $\mathrm{Phth}\left(\mathrm{SO}_{3}\right)-\mathrm{Cy5}-\mathrm{COOH}$ dye was prepared. Following its coupling to $c[\mathrm{RGDyK}]$ using standard NHS chemistry, this heterobifunctional $\mathrm{Cy} 5$ dye functioned as a linker unit for further synthetic modifications. By using an adapted version of the Gabriel synthesis, the amine could easily be liberated. Subsequent diazotransfer ${ }^{24}$ with $1 \mathrm{H}$-imidazolesulfonyl azide. $\mathrm{HCl}$ could be performed, which resulted in $\mathbf{N}_{3}\left(\mathbf{S O}_{3}\right)$-Cy5c[RGDyK]. This modification supported SPAAC with either DBCO-DTPA or BCN-DTPA, resulting in DTPA.DBCO. $\mathrm{N}_{3}\left(\mathrm{SO}_{3}\right)-\mathrm{Cy} 5-\mathrm{c}[\mathrm{RGDYK}]$ and DTPA.BCN.N $\mathrm{N}_{3}\left(\mathrm{SO}_{3}\right)$ Cy5-c[RGDyK], respectively (Scheme 1).

Photophysical and Chemical Properties. To assess the influence that the chemical alterations exerted on the dyes' and hybrid tracers' photophysical properties, the molar extinction coefficient $(\varepsilon)$ and quantum yield $\left(\Phi_{\mathrm{F}}\right)$ were assessed to evaluate the brightness $\left(\varepsilon \cdot \Phi_{\mathrm{F}}\right)$.

Solvent polarity plays a large role in $\varepsilon$; the $\varepsilon$ value of $\mathbf{N}_{3}\left(\mathrm{SO}_{3}\right)$ Cy5-COOH in dimethyl sulfoxide (DMSO) was reduced by $40 \%$ when changing to $\mathrm{H}_{2} \mathrm{O}\left(218 \times 10^{3} \mathrm{M}^{-1} \mathrm{~cm}^{-1}\right.$ in DMSO vs $131 \times 10^{3} \mathrm{M}^{-1} \mathrm{~cm}^{-1}$ in $\mathrm{H}_{2} \mathrm{O}$ ), and a $13 \%$ reduction was seen when phosphate-buffered saline (PBS) was used $\left(189 \times 10^{3} \mathrm{M}^{-1}\right.$ $\left.\mathrm{cm}^{-1}\right)$, which is in line with previous results. ${ }^{22}$ The relative $\Phi_{\mathrm{F}}$ of $\mathbf{N}_{3}\left(\mathbf{S O}_{3}\right)$-Cy5-COOH was similar to methyl-Cy5-COOH ${ }^{22}$ (precursor to DTPA-Lys (Cy5 $\left(\mathrm{SO}_{3}\right)$ methyl)-Cys-c[RGDyK]; $\Phi_{\mathrm{F}}=13 \%$ for both dyes in PBS).

The brightness of the precursor for the triazole-based hybrid tracers $\left(\mathrm{N}_{3}\left(\mathbf{S O}_{3}\right)-\mathbf{C y 5}-\mathbf{C O O H}\right)$ was in the same range as the precursor for the end-labeled design (methyl-Cy5-COOH; 29 $\times 10^{3}$ vs $28 \times 10^{3} \mathrm{M}^{-1} \mathrm{~cm}^{-1}$, respectively). When the click reaction incorporating $\mathrm{DBCO}$ was used to form DTPA.DBCO. $\mathrm{N}_{3}\left(\mathrm{SO}_{3}\right)$-Cy5-c[RGDyK], virtually no change in brightness was observed compared to $\mathbf{N}_{3}\left(\mathbf{S O}_{3}\right)$-Cy5-COOH $(23 \times$ $10^{3}$ vs $25 \times 10^{3} \mathrm{M}^{-1} \mathrm{~cm}^{-1}$, respectively). The brightness was, however, enhanced to $40 \times 10^{3} \mathrm{M}^{-1} \mathrm{~cm}^{-1}$ for DTPA.BCN. $\mathbf{N}_{3}\left(\mathrm{SO}_{3}\right)$-Cy5-c[RGDyK]. The reference tracer DTPA-Lys(Cy5(SO S $_{3}$ methyl)-Cys-c[RGDyK] had an even higher brightness $\left(50 \times 10^{3} \mathrm{M}^{-1} \mathrm{~cm}^{-1}\right)$. Cis-trans isomerization around the polymethine bridge plays a large role in the differences in brightness, ${ }^{25}, 26$ but since the BCN moiety is considerably less bulky than its DBCO counterpart, it seems that intra- or intermolecular interactions other than steric hindrance caused this effect.

By using the shake-flask method with radiolabeled hybrid tracer, the partition coefficients in octanol/ $\mathrm{H}_{2} \mathrm{O}\left(\log P_{(\mathrm{o} / \mathrm{w})}\right)$ were determined for all three hybrid tracers as $\log P_{(\mathrm{o} / \mathrm{w})}=-2.55$ $\pm 0.10,-1.45 \pm 0.03$, and $-2.67 \pm 0.12$ for $\left[{ }^{99 \mathrm{mTc}}\right]$ DTPA.DBCO. $\mathrm{N}_{3}\left(\mathrm{SO}_{3}\right)$ - Cy 5 -c [RGDyK], [99 T T $]$ DTPA.BCN.N ${ }_{3}\left(\mathrm{SO}_{3}\right)-\mathrm{Cy} 5-\mathrm{c}[\mathrm{RGDyK}]$, and [ $\left.{ }^{99 \mathrm{mTc}}\right] \mathrm{DTPA}-$ 

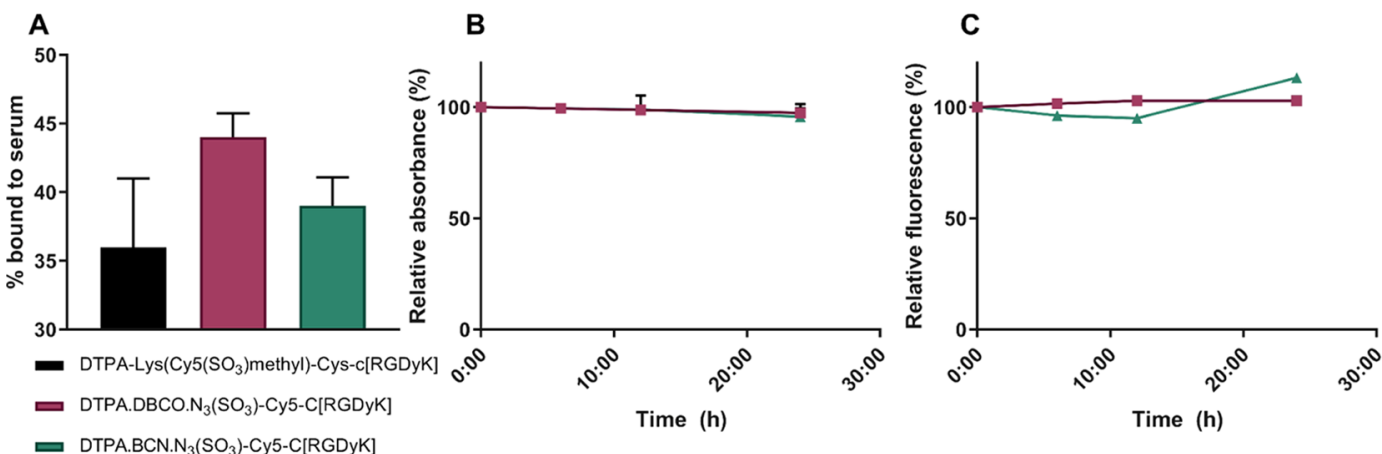

Figure 1. Plasma protein interactions portraying $(\mathrm{A})$ no significant difference $(p>0.05)$ in the plasma protein binding of the heterobifunctional tracers compared to the alternative branched design and high stability over a $24 \mathrm{~h}$ timespan for both heterobifunctional tracers using (B) absorbance and (C) fluorescence measurements.

(A)
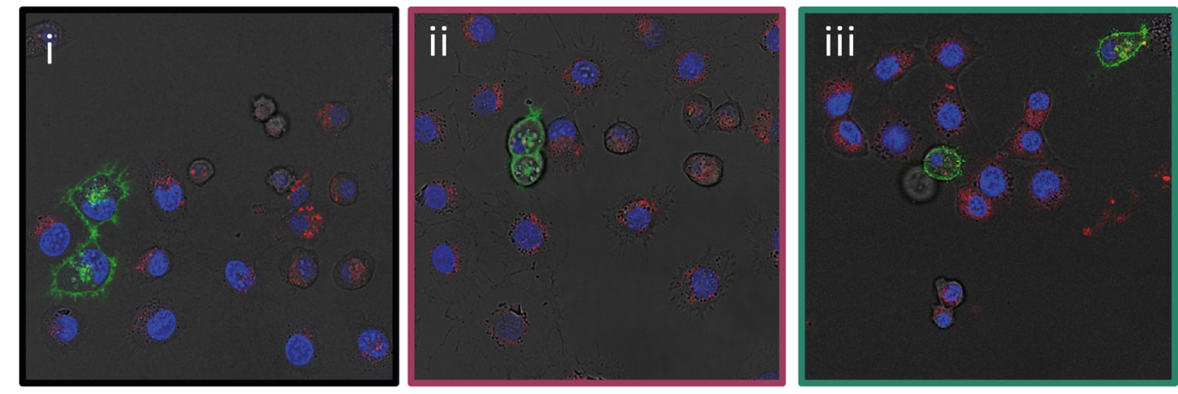

(B)
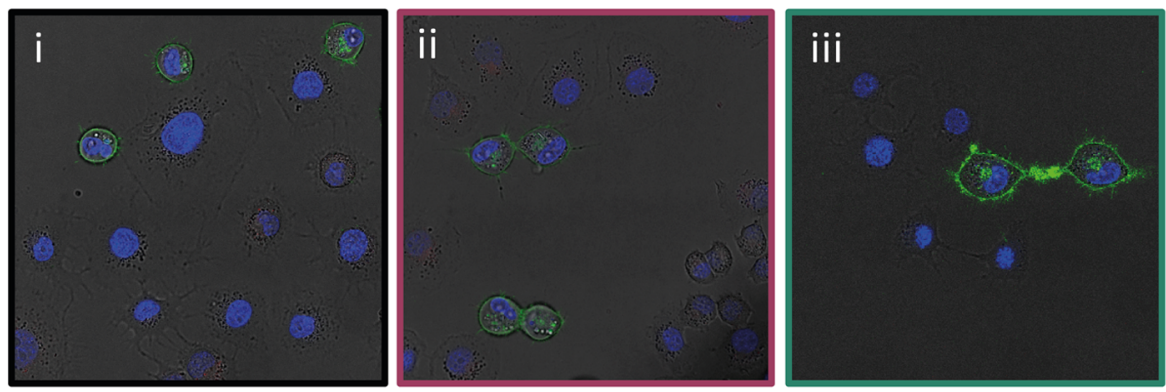

(C)

(D)
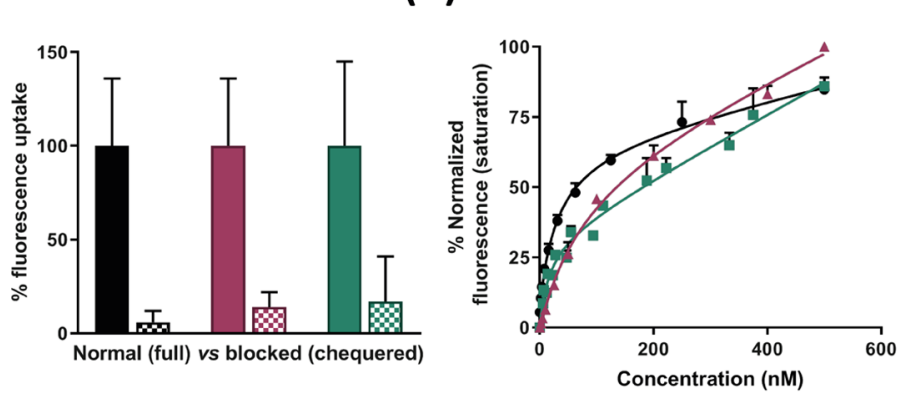

$\rightarrow \mathrm{k}_{\mathrm{D}}=30.3+5.7 \mathrm{nM}$

$\neq \mathrm{k}_{\mathrm{D}}=17.5 \pm 6.0 \mathrm{nM}$

$\rightarrow \mathrm{k}_{\mathrm{D}}=76.5 \pm 18.3 \mathrm{nM}$

DTPA-Lys $\left(C y 5\left(\mathrm{SO}_{3}\right)\right.$ methyl)-Cys-C[RGDyK] $\square$ DTPA.DBCO.N ${ }_{3}\left(\mathrm{SO}_{3}\right)-\mathrm{Cy} 5-\mathrm{C}[\mathrm{RGDyK}] \square$ DTPA.BCN.N $\mathrm{N}_{3}\left(\mathrm{SO}_{3}\right)-\mathrm{Cy} 5-\mathrm{C}[\mathrm{RGDyK}]$

Figure 2. In vitro evaluation of the hybrid tracers. Fluorescence confocal microscopy images of a mixed-cell culture of (A) $\alpha_{\mathrm{V}} \beta_{3}$-positive Ge $\beta 3$ and $\alpha_{\mathrm{V}} \beta_{3}$-negative MDAMB231 X4 cells incubated with the reference tracer (i) DTPA-Lys(Cy5(SO $\left.{ }_{3}\right)$ methyl)-Cys-c[RGDyK], (ii) DTPA.DBCO. $\mathrm{N}_{3}\left(\mathrm{SO}_{3}\right)$-Cy5-c[RGDyK], (iii) DTPA.BCN.N ${ }_{3}\left(\mathrm{SO}_{3}\right)-\mathrm{Cy} 5-\mathrm{c}[\mathrm{RGDyK}]$. (B) The same cell lines after blocking with c[RGDyK] prior to incubation with one of the hybrid tracers. For additional reference, cell nuclei were stained with Hoechst (in blue), and the intrinsic membranous GFP expression of the MDAMB231 X4 cells was used to discriminate between the two cell lines (bright green). (C) Quantified evaluation of the percentage of signal decrease between (A) and (B) (blocked; checkered) $p<0.0001, n \geq 13$. (D) Combined saturation curves of the affinity of DTPALys $\left(\mathrm{Cy} 5\left(\mathrm{SO}_{3}\right)\right.$ methyl)-Cys-c[RGDyK], DTPA.DBCO.N ${ }_{3}\left(\mathrm{SO}_{3}\right)-\mathrm{Cy} 5-\mathrm{c}[\mathrm{RGDyK}]$, and DTPA.BCN.N ${ }_{3}\left(\mathrm{SO}_{3}\right)-\mathrm{Cy5}$-c $[\mathrm{RGDyK}]$ (with the binding affinity $\left(K_{\mathrm{D}}\right)$ of the tracers in nanomolar $), n=3$.

Lys(Cy5( SO $\left._{3}\right)$ methyl)-Cys-c[RGDyK], respectively (Table $1)$. These data indicated, surprisingly, that $\left[{ }^{99 \mathrm{mTc}}\right]^{-}$ DTPA.BCN. $\mathbf{N}_{3}\left(\mathrm{SO}_{3}\right)$-Cy5-c[RGDyK] was the most lipophilic compound of the three, while $\left[{ }^{99 \mathrm{mTc}}\right]$ DTPA.DBCO. $\mathrm{N}_{3}\left(\mathrm{SO}_{3}\right)$ -
Cy5-c[RGDyK] and the reference tracer [ ${ }^{99 \mathrm{mTc}}$ ]DTPA-Lys(Cy5 $\left(\mathrm{SO}_{3}\right)$ methyl)-Cys-c[RGDyK] had similar lipophilicities. Serum Interaction and Chemical Stability. Depending on their functionalization, cyanine dyes can form strong 
(A)

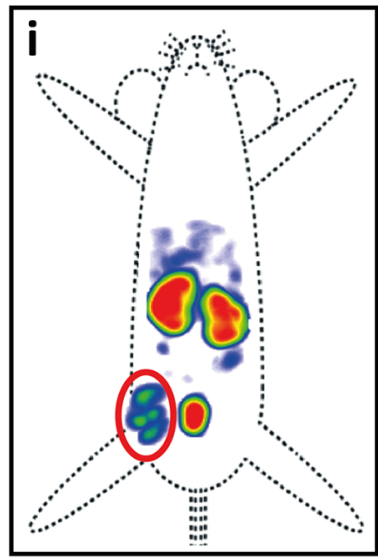

(B)

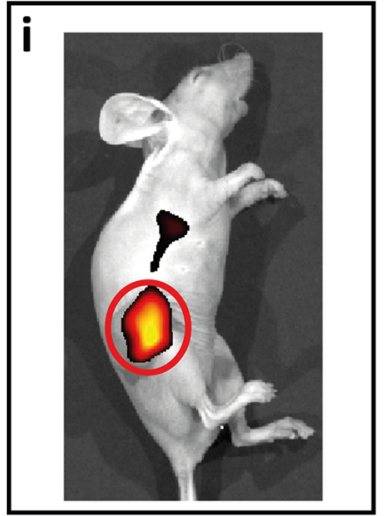

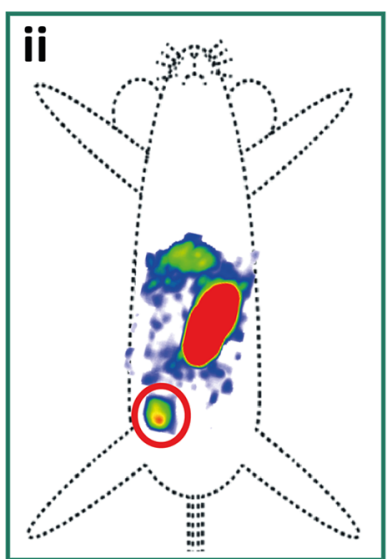

ii

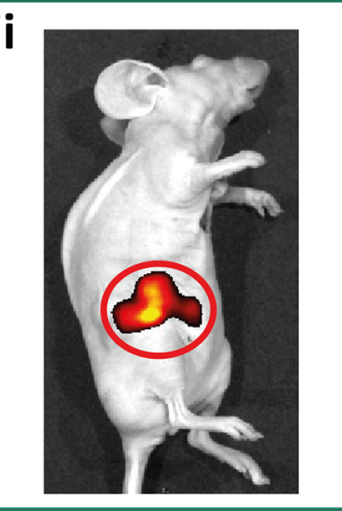

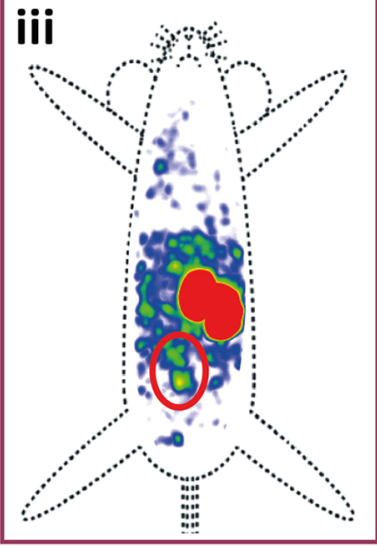

iii

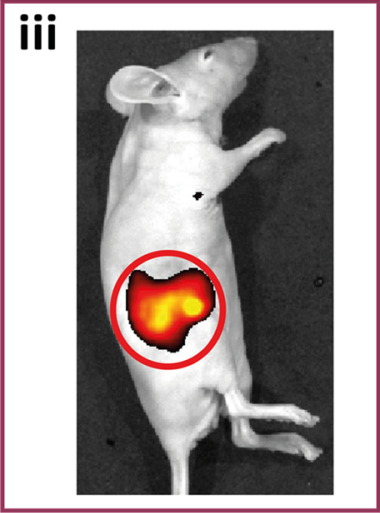

(C)

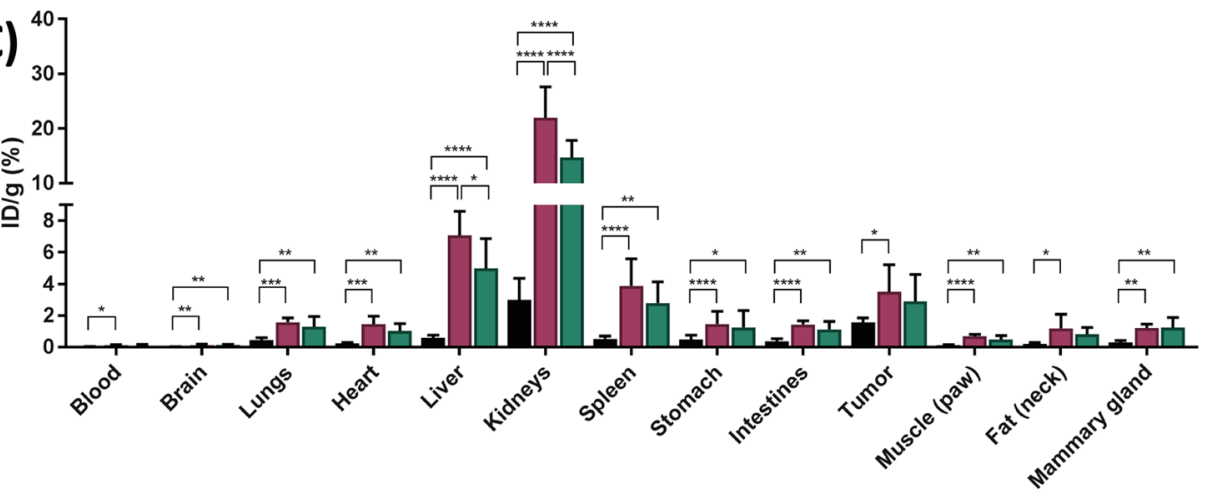

DTPA-Lys $\left(\mathrm{Cy}_{5}\left(\mathrm{SO}_{3}\right)\right.$ methyl)-Cys-c[RGDyK] $\square$ DTPA.DBCO.N ${ }_{3}\left(\mathrm{SO}_{3}\right)$-Cy5-C[RGDyK]

$\square$ DTPA.BCN. $\mathrm{N}_{3}\left(\mathrm{SO}_{3}\right)$-Cy5-C[RGDyK]

Figure 3. In vivo imaging and biodistribution. In vivo (A) SPECT images and (B) accompanying fluorescence images of 4T1-tumor-bearing mice acquired at $24 \mathrm{~h}$ after administration of $1 \mathrm{nmol}$ of the reference tracer $\left[{ }^{111} \mathrm{In}\right] \mathrm{DTPA}-\mathrm{Lys}\left(\mathrm{Cy} 5\left(\mathrm{SO}_{3}\right)\right.$ methyl)-Cys-c[RGDyK] (i), [111 In]DTPA.DBCO. $\mathrm{N}_{3}\left(\mathrm{SO}_{3}\right)-\mathrm{Cy5}-\mathrm{c}[\mathrm{RGDyK}]$ (ii), and [ $\left.{ }^{111} \mathrm{In}\right] \mathrm{DTPA} \cdot \mathrm{BCN} \cdot \mathrm{N}_{3}\left(\mathrm{SO}_{3}\right)-\mathrm{Cy} 5-\mathrm{c}[\mathrm{RGDyK}]$ (iii). Tumor is encircled in red. (C)

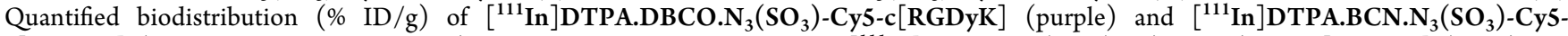
c[RGDyK] (green; $n=6$ per compound). For reference, biodistribution of $\left[{ }^{111}\right.$ In]DTPA-Lys(Cy5(SO $\left.{ }_{3}\right)$ methyl)-Cys-c[RGDyK] (black) was included as previously presented by Bunschoten et al. ${ }^{17}$ Significance between the hybrid triazole-containing RGD conjugates and the reference annotated as: $* * * * p \leq 0.0001, * * * p \leq 0.001, * * p \leq 0.01, * p \leq 0.05$, and $\mathrm{ns}=p>0.05$.

noncovalent bonds with serum proteins, e.g., albumin. In addition, the dyes can also be metabolically degraded, ${ }^{17,21,22,27,28}$ yielding circulation of tracer fragments in an in vivo setting. Such degradation underlines the pressing need for serum interaction assays during preclinical research. A serum binding assay for the two triazole-containing RGD-targeting hybrid tracers revealed no significant differences between the two click analogues ( $44 \pm 2 \%$ bound for DTPA.DBCO. $\mathrm{N}_{3}\left(\mathrm{SO}_{3}\right)$-Cy5-c[RGDyK] and $40 \pm 2 \%$ bound for DTPA.BCN. $\mathbf{N}_{3}\left(\mathrm{SO}_{3}\right)$-Cy5-c[RGDyK]; Figure 1A) and the reference tracer DTPA-Lys $\left(\mathrm{Cy5}\left(\mathrm{SO}_{3}\right)\right.$ methyl)-Cys-c-
[RGDyK] (36 $\pm 5 \%$ bound; $p>0.05$ for all comparisons $){ }^{17}$ Hence, the difference in lipophilicity did not seem to affect the serum binding ability of the different hybrid traceranalogues.

Dye stabilities of $>94 \%$ were found after incubation with nonheat-inactivated serum $\left(24 \mathrm{~h} ; 37^{\circ} \mathrm{C}\right)$, which was in line with earlier reports for $\mathrm{Cy} 5$ dyes $^{22,29}$ (Figure 1B,C).

In Vitro Localization and Receptor Affinity. Fluorescence confocal imaging in mixed-cell culture experiments revealed comparable uptake of the reference tracer DTPALys $\left(\mathrm{Cy5}\left(\mathrm{SO}_{3}\right)\right.$ methyl)-Cys-c[RGDyK] (Figure 2Ai) in $\alpha_{\mathrm{V}} \beta_{3}$ positive cells (Cy5-related uptake in red) compared to both 
DTPA.DBCO.N $\mathrm{N}_{3}\left(\mathrm{SO}_{3}\right)$-Cy5-c[RGDyK] (Figure 2Aii) and DTPA.BCN.N $\mathbf{N}_{3}\left(\mathrm{SO}_{3}\right)-\mathrm{Cy} 5$-c [RGDyK] (Figure 2Aiii). Uptake in $\alpha_{\mathrm{V}} \beta_{3}$-negative cells present in the mixed-cell culture was not seen (Figure 2A,B, with green fluorescent protein (GFP)-tagged membranous reference in bright green). Blocking studies confirmed selective binding of the tracers to $\alpha_{\mathrm{V}} \beta_{3}$ (Figure 2B); incubation with unlabeled $\mathbf{c}[\mathbf{R G D y K}]$ resulted in a statistically significant decrease in uptake of the reference tracer DTPA-Lys $\left(\mathrm{Cy} 5\left(\mathrm{SO}_{3}\right)\right.$ methyl)-Cys-c[RGDyK] $(94 \pm 6 \%)$ and both triazole-containing tracers DTPA.DBCO. $\mathrm{N}_{3}\left(\mathrm{SO}_{3}\right)$-Cy5c[RGDyK] $(86 \pm 8 \%)$ and DTPA.BCN.N ${ }_{3}\left(\mathrm{SO}_{3}\right)$-Cy5c[RGDyK] ( $83 \pm 24 \%$; Figure 2C; $p<0.0001)$.

Flow-cytometry-based affinity measurements showed that the affinity of DTPA.DBCO.N $\mathrm{N}_{3}\left(\mathrm{SO}_{3}\right)$-Cy5-c[RGDyK] for the $\alpha_{\mathrm{v}} \beta_{3}$ integrin $\left(K_{\mathrm{D}}=17.5 \pm 6.0\right.$; Figure $\left.2 \mathrm{D}\right)$ was significantly increased compared to the previously reported affinity of the reference tracer DTPA-Lys $\left(\mathrm{Cy5}\left(\mathrm{SO}_{3}\right)\right.$ methyl)-Cys-c[RGDyK] $\left(K_{\mathrm{D}}=\right.$ $30.3 \pm 5.7, p>0.0001$; Figure $2 \mathrm{D}$, black). ${ }^{17,21}$ The receptor affinity of DTPA.BCN.N $\mathrm{N}_{3}\left(\mathrm{SO}_{3}\right)$-Cy5-c[RGDyK] was significantly lower $\left(K_{\mathrm{D}}=76.5 \pm 18.3, p>0.0001\right.$; Figure $2 \mathrm{D}$, green $)$ than that of the reference tracer DTPA-Lys $\left(\mathrm{Cy5}\left(\mathrm{SO}_{3}\right)\right.$ methyl)Cys-c[RGDyK], but still in the lower nanomolar range.

In Vivo Imaging and Biodistribution. To assess the effect of implementation of triazole-based click chemistry on the in vivo targeting efficiency and pharmacokinetics of the RGD tracers, [ ${ }^{111}$ In]DTPA.DBCO. $\mathrm{N}_{3}\left(\mathrm{SO}_{3}\right)$-Cy5-c[RGDyK] and [ $\left.{ }^{111} \mathrm{In}\right]$ DTPA.BCN.N $\mathrm{N}_{3}\left(\mathrm{SO}_{3}\right)$-Cy5-c[RGDyK] were directly compared to the end-conjugated reference tracer $\left[{ }^{111} \mathbf{I n}\right]$ DTPA-Lys $\left(\mathrm{Cy} 5\left(\mathrm{SO}_{3}\right)\right.$ methyl)-Cys-c[RGDyK]. To this end, single-photon emission computed tomography (SPECT) imaging (Figure $3 \mathrm{~A}$ ), fluorescence imaging (Figure $3 \mathrm{~B}$ ), and quantitative assessment of the in vivo biodistribution of [ $\left.{ }^{111} \mathrm{In}\right]$ DTPA.DBCO. $\mathrm{N}_{3}\left(\mathrm{SO}_{3}\right)-\mathrm{Cy} 5-\mathrm{c}[\mathrm{RGDyK}]$ and $\left[{ }^{111} \mathrm{In}\right]-$ DTPA.BCN. ${ }_{3}\left(\mathrm{SO}_{3}\right)$-Cy5-c[RGDyK] (Figure 3C) were performed using identical experimental settings as used previously (i.e., at $24 \mathrm{~h}$ after intravenous administration of 1 nmol of the respective hybrid RGD tracer derivative). ${ }^{17,21}$ Both SPECT and fluorescence imaging of tumor-bearing mice resulted in tumor visualization after administration of [ $\left.{ }^{111} \mathbf{I n}\right]$ DTPA-Lys $\left(\mathrm{Cy} 5\left(\mathrm{SO}_{3}\right)\right.$ methyl)-Cys-c[RGDyK], [ [111 In]DTPA.DBCO. $\mathrm{N}_{3}\left(\mathrm{SO}_{3}\right)$-Cy5-c[RGDyK], or $\left[{ }^{111} \mathrm{In}\right]$ DTPA.BCN.N ${ }_{3}\left(\mathrm{SO}_{3}\right)$-Cy5-c[RGDyK] (Figure 3A,B, respectively, $\mathrm{i}$ and ii; tumor encircled in red). Besides tumor visualization, SPECT imaging also enabled visual assessment of the biodistribution of the hybrid tracers, revealing a dominant kidney accumulation for all compounds (Figure 3A) and a relatively high uptake in other nontargeted organs for [ $\left.{ }^{111} \mathrm{In}\right]$ DTPA.BCN.N ${ }_{3}\left(\mathrm{SO}_{3}\right)$-Cy5-c[RGDyK] (Figure 3Aiii). It was suspected that the visibility of the tumor when using [ $\left.{ }^{111} \mathrm{In}\right]$ DTPA.BCN.N ${ }_{3}\left(\mathrm{SO}_{3}\right)$-Cy5-c[RGDyK] was further impeded by the location of the tumor.

The ex vivo biodistribution data not only underlined the imaging observations but also revealed differences (Figure 3C), e.g., in tumor uptake: [ $\left.{ }^{111} \mathrm{In}\right]$ DTPA.DBCO.N $\mathrm{N}_{3}\left(\mathrm{SO}_{3}\right)$-Cy5c[RGDyK] and [ $\left.{ }^{111} \mathrm{In}\right]$ DTPA.BCN.N $\mathrm{N}_{3}\left(\mathrm{SO}_{3}\right)$-Cy5-c[RGDyK] have tumor uptakes of $3.5 \pm 1.7$ and $2.9 \pm 1.7 \% \mathrm{ID} / \mathrm{g}$, respectively. [ $\left.{ }^{111} \mathrm{In}\right] \mathrm{DTPA}-\mathrm{Lys}\left(\mathrm{Cy} 5\left(\mathrm{SO}_{3}\right)\right.$ methyl)-Cys-c[RGDyK], with a tumor uptake of $1.6 \pm 0.3 \% \mathrm{ID} / \mathrm{g}$, is significantly different from $\left[{ }^{111} \mathrm{In}\right] \mathrm{DTPA} . \mathrm{DBCO} . \mathrm{N}_{3}\left(\mathrm{SO}_{3}\right)$ Cy5-c[RGDyK] $(p=0.0312)$, but is in the same range as [111 In]DTPA.BCN.N ${ }_{3}\left(\mathrm{SO}_{3}\right)$-Cy5-c[RGDyK] $(p>0.05)$. The tumor-to-muscle ratios (T/M) of both $\left[{ }^{111} \mathrm{In}\right]$ DTPA.DBCO. $\mathrm{N}_{3}\left(\mathrm{SO}_{3}\right)$-Cy5-c[RGDyK] $(4.8 \pm 2.1)$ and $\left[{ }^{111} \mathrm{In}\right]$ DTPA.BCN.N ${ }_{3}\left(\mathrm{SO}_{3}\right)$-Cy5-c[RGDyK $](5.1 \pm 1.5)$ were, however, clearly negatively affected by nonspecific signal present in adjoining muscle tissue; compared to these two tracers, the $\mathrm{T} / \mathrm{M}$ of the reference tracer $\left[{ }^{111} \mathrm{In}\right] \mathrm{DTPA}$ $\operatorname{Lys}\left(\mathrm{Cy} 5\left(\mathrm{SO}_{3}\right)\right.$ methyl)-Cys-c[RGDyK] was found to be superior (12.8 $\pm 1.8 ; p<0.0001$ for both comparisons). Nevertheless, the tumors could still be visualized in vivo with fluorescence imaging despite the lower $\mathrm{T} / \mathrm{M}$ (Figure 3B).

Affinity values are generally used to explain $\mathrm{T} / \mathrm{M}$ ratios. ${ }^{17}$ In this case, however, the measured affinities did not directly link to the tumor uptake or $\mathrm{T} / \mathrm{M}$ ratios; both $\left[{ }^{111} \mathrm{In}\right]$ DTPA.DBCO.N $\mathrm{N}_{3}\left(\mathrm{SO}_{3}\right)$-Cy5-c[RGDyK] and [ $\left.{ }^{111} \mathrm{In}\right]$ DTPA.BCN.N ${ }_{3}\left(\mathrm{SO}_{3}\right)$-Cy5-c[RGDyK] have an affinity in the same nanomolar range as [ $\left.{ }^{111} \mathrm{In}\right] \mathrm{DTPA}-\mathrm{Lys}\left(\mathrm{Cy5}\left(\mathrm{SO}_{3}\right)\right.$ methyl)-Cys-c[RGDyK], but their $\mathrm{T} / \mathrm{M}$ ratio is significantly reduced compared to the reference tracer $\left[{ }^{111}\right.$ In] DTPALys $\left(\mathrm{Cy} 5\left(\mathrm{SO}_{3}\right)\right.$ methyl)-Cys-c [RGDyK] $(p<0.0001)$. Other than affinity, differences in charge, lipophilicity, and/or serum binding also influence the $\mathrm{T} / \mathrm{M}$ ratio. In this case, a trend (albeit nonsignificant) was observed for serum binding ([$\left[{ }^{111} \mathbf{I n}\right]$ DTPA.DBCO. $\mathrm{N}_{3}\left(\mathrm{SO}_{3}\right)$-Cy5-c[RGDYK $]>\left[{ }^{111} \mathrm{In}\right]-$ DTPA.BCN. ${ }_{3}\left(\mathrm{SO}_{3}\right)$-Cy5-c[RGDyK] $>{ }^{[111}$ In]DTPA-Lys$\left(\mathrm{Cy5}\left(\mathrm{SO}_{3}\right)\right.$ methyl)-Cys-c[RGDyK]; see Figure $\left.1 \mathrm{~A} ; n=3\right)$, which seemed to translate to changes in the biodistribution values; in vivo, the trend became more pronounced and differences were statistically significant. The fact that this uptake pattern was similar for all of the evaluated organs (Figure 3C; $n=$ 6) further suggested a generic effect; serum binding has e.g. been the culprit for such observations in previously reported results. $^{28}$

For all compounds, renal retention was by far the highest, and the uptake of [ $\left.{ }^{111} \mathrm{In}\right]$ DTPA.DBCO.N $\mathrm{N}_{3}\left(\mathrm{SO}_{3}\right)-\mathrm{Cy} 5-\mathrm{c}[\mathrm{RGDyK}]$ and [ $\left.{ }^{111} \mathrm{In}\right]$ DTPA.BCN.N $\mathrm{N}_{3}\left(\mathrm{SO}_{3}\right)$-Cy5-c[RGDyK] was significantly higher compared to that of the reference tracer [111 In]DTPA-Lys(Cy5( SO $\left._{3}\right)$ methyl)-Cys-c[RGDyK] (14.7 $\pm 3.2,22.0 \pm 5.7$, and $3.0 \pm 1.4 \% \mathrm{ID} / \mathrm{g}$, respectively; $p \leq$ $0.0001)$. As the $\alpha_{\mathrm{v}} \beta_{3}$ integrin is ubiquitous in the kidney, some renal accumulation of the RGD-containing conjugates can be expected; ${ }^{30,31}$ however, considering conditions between groups were identical, this explanation appeared inadequate. This effect could also not be explained based on the lipophilicity of the compounds (see above). Hence, it seems that the increase in renal uptake of the triazole-containing RGD hybrid tracers is attributable to the introduction of triazole-containing moieties formed by click chemistry. Literature indicates that some triazoles, e.g., Isavuconazole, are characterized by prolonged high kidney uptake ${ }^{32}$ and that 3-amino-1,2,3-triazole irreversibly binds to catalase proteins, ${ }^{33,34}$ thus implying that these moieties may induce this behavior. It is generally known that molecular alterations and their size have an undisputed effect on the biodistribution, but no prior research regarding the influence of the moieties resulting from copper-free click chemistry has been published to date to the best of our knowledge.

Besides SPAAC and its triazole product, other forms of bioorthogonal click chemistry such as the isocyanide $[4+1]$ cyclocaddition or inverse electron demand Diels-Alder (IEDDA) could also be employed in the design of a hybrid tracer. However, while IEDDA $\left(k=1-10 \times 10^{6} \mathrm{M}^{-1} \mathrm{~s}^{-1}\right)$ is considerably faster than SPAAC $\left(k=10^{-2}-1 \mathrm{M}^{-1} \mathrm{~s}^{-1}\right)^{35}$ and has been used previously in pretargeting strategies, ${ }^{36,37}$ the effect of IEDDA on the in vivo characteristics of a tracer without an antibody has not yet been investigated. That being said, given the relatively large effects that the triazole-containing moieties 
have been shown to exert, it would be of great interest to compare the effect of both types of copper-free click chemistry in an in vivo setting.

As previously mentioned, the 1,2,3-triazole-containing moiety introduced by click chemistry seemed to have a negative effect on the pharmacokinetics of RGD-based hybrid tracers, but the utility of the heterobifunctional design regarding other targets and/or other targeting moieties should be considered in future studies considering e.g. receptor pockets can vary. The composition of the hybrid tracer plays a large role in the pharmacokinetics of small-molecule-based hybrid tracers, ${ }^{20}$ but such an effect could prove negligible with larger structures such as nanobody-, antibody-, or nanoparticle-based hybrid tracers. Further exploration of whether this design holds promise for other targets, with or without click chemistry, is thus warranted.

\section{CONCLUSIONS}

Despite the tracer's stability and good in vitro performance of triazole-based hybrid tracers, biodistribution data indicated that incorporation of the relatively bulky chemical modifications used for the copper-free click conjugation in RGD-targeting hybrid tracer design has a negative effect on its pharmacokinetics, although the tumors could still be visualized. Thus, the design could hold promise for other targets and/or targeting moieties.

\section{METHODS}

All chemicals were obtained from commercial sources and used without further purification. Solvents were obtained from ActuAll Chemicals (Oss, The Netherlands) in high-performance liquid chromatography (HPLC) or peptide grade and used without further purification. The reactions were monitored by thin-layer chromatography (TLC) and/or mass spectrometry using a Bruker microflex LRF matrix-assisted laser desorption/ ionization time-of-flight (MALDI-TOF). HPLC was performed on a Waters (Etten-Leur, The Netherlands) HPLC system using a $1525 \mathrm{EF}$ pump and a $2489 \mathrm{UV} /$ vis detector. For preparative HPLC, a Dr. Maisch GmbH (Ammerbuch, Germany) ReprosilPur $120 \mathrm{C} 18$-AQ $10 \mu \mathrm{m}\left(250 \times 20 \mathrm{~mm}^{2}\right)$ column was used $(12$ $\mathrm{mL} / \mathrm{min}$ ). For semipreparative HPLC, a Dr. Maisch $\mathrm{GmbH}$ Reprosil-Pur C18-AQ $10 \mu \mathrm{m}\left(250 \times 10 \mathrm{~mm}^{2}\right)$ or a Waters XBridge BEH C8 $10 \mu \mathrm{m}\left(250 \times 10 \mathrm{~mm}^{2}\right)$ Prep OBD column was used $(5 \mathrm{~mL} / \mathrm{min})$. For analytical HPLC, a Dr. Maisch GmbH Reprosil-Pur C18-AQ $5 \mu \mathrm{m}\left(250 \times 4.6 \mathrm{~mm}^{2}\right)$ column was used. For all HPLC runs, a gradient of $0.1 \%$ trifluoroacetic acid (TFA) in $\mathrm{H}_{2} \mathrm{O} / \mathrm{CH}_{3} \mathrm{CN} 95: 5$ to $0.1 \%$ TFA in $\mathrm{H}_{2} \mathrm{O}$ / $\mathrm{CH}_{3} \mathrm{CN}$ 5:95 in $40 \mathrm{~min}$ was used. Nuclear magnetic resonance (NMR) spectra were taken using a Bruker DPX-300 spectrometer (300 MHz ${ }^{1} \mathrm{H} \mathrm{NMR}, 75 \mathrm{MHz}{ }^{13} \mathrm{C} \mathrm{NMR}$ ), and chemical shifts $(\delta)$ are reported relative to TMS $(\delta=0)$ and/or referenced to the solvent in which they were measured. Abbreviations used include singlet ( $\mathrm{s}$ ), doublet (d), doublet of doublets $(\mathrm{dd})$, triplet $(\mathrm{t})$, and unresolved multiplet $(\mathrm{m})$. Full ${ }^{1} \mathrm{H}$ NMR spectra are provided in the Supporting Information available online.

Synthesis. $\left(\mathrm{SO}_{3}\right)$ Indole, Indole, and Indole- $\mathrm{COOH}$. $\left(\mathrm{SO}_{3}\right)$ Indole, Indole and Indole-COOH were synthesized according to earlier published procedures. ${ }^{38}$ All products were directly used without further purification.

$\left(\mathrm{SO}_{3}\right)$ Indole-Amine C4Phth. ( $\left.\mathrm{SO}_{3}\right)$ Indole-AmineC4Phth was synthesized inspired by adjusted synthesis methods. ${ }^{38,39}$ Briefly, $\left(\mathrm{SO}_{3}\right)$ Indole $(25 \mathrm{mmol})$ and 1-(4-bromobutyl)- pyrrolidine-2,5-dione $(75.0 \mathrm{mmol})$ were dissolved in sulfolane $(40 \mathrm{~mL})$ and left stirring at $90{ }^{\circ} \mathrm{C}$ for $24 \mathrm{~h}$ under nitrogen atmosphere. The resulting mixture was, after cooling down to room temperature (r.t.), precipitated by adding to $\mathrm{CH}_{3} \mathrm{OH}$. The product was washed twice with ethyl acetate and diethyl ether and dried in vacuo, resulting in a brownish powder $(5.9 \mathrm{~g})$, which was used without any further purification.

DTPA-NHS. DTPA $(t \mathrm{Bu})_{4}(100.0 \mathrm{mg}, 161.9 \mu \mathrm{mol})$, dipyrrolidino( $N$-succinimidyloxy)carbenium hexafluorophosphate (HSPyU) $(73.0 \mathrm{mg}, 178.1 \mu \mathrm{mol})$, and $N, N$-diisopropylethylamine (DiPEA) $(141.0 \mu \mathrm{L}, 809.3 \mu \mathrm{mol})$ were dissolved in $\mathrm{CH}_{2} \mathrm{Cl}_{2}$ (5 mL, dried on $4 \AA$ molecular sieves) and stirred for 15 $\mathrm{h}$ at r.t. The crude product was used without further purification in the following reaction steps. $m / z[\mathrm{M}+\mathrm{H}]^{+}$calcd. 715.9, found 715.5.

DTPA-Ethylene Diamine. DTPA-NHS $(57.5 \mathrm{mg}, 93.1 \mu \mathrm{mol})$, $N$-Boc-ethylenediamine $(12.8 \mu \mathrm{L}, 81.0 \mu \mathrm{mol})$, and DiPEA $(28.2$ $\mu \mathrm{L}, 160.9 \mu \mathrm{mol})$ in $\mathrm{CH}_{2} \mathrm{Cl}_{2}(2.5 \mathrm{~mL})$ were stirred for $30 \mathrm{~min}$ until full conversion according to TLC and MALDI-TOF. The solvent was removed in vacuo and 95:5 TFA/ $\mathrm{H}_{2} \mathrm{O}(2 \mathrm{~mL})$ was added followed by stirring for $2 \mathrm{~h}$. The product was precipitated in diethyl ether $(45 \mathrm{~mL})$, centrifuged, and decanted. This was repeated twice, and the precipitate was desiccated and used without further purification. $m / z[\mathrm{M}+\mathrm{H}]^{+}$calcd. 436.4, found 436.0.

DTPA-DBCO. DTPA-ethylene diamine $(23.0 \mu \mathrm{mol})$ and triethylamine $(23.0 \mu \mathrm{mol})$ were dissolved in dimethylformamide (DMF) $(120.0 \mu \mathrm{L})$ and stirred at $30{ }^{\circ} \mathrm{C}$. DBCO-NHS $(15.3 \mu \mathrm{mol})$ was dissolved in DMF $(580 \mu \mathrm{L})$ and added to the DTPA-ethylene diamine solution before stirring at $30^{\circ} \mathrm{C}$ for $7 \mathrm{~h}$. Subsequently, DiPEA $(115.0 \mu \mathrm{mol})$ was added and the mixture was stirred at $30{ }^{\circ} \mathrm{C}$ overnight before cooling down to r.t. and precipitating in ice-cold diethyl ether. The precipitate was collected, and residual solvents were removed in vacuo. The crude, white solid was purified by prep-HPLC to obtain a white solid $(0.8 \mathrm{mg})$, which was used without any further purification.

$D T P A-B C N$. DTPA-ethylene diamine $(121 \mu \mathrm{mol})$ was dissolved in DMSO $(800 \mu \mathrm{L})$. BCN-NHS $(81 \mu \mathrm{mol}$, purchased at Sigma-Aldrich Cat. No. 744867) and DIPEA $(810 \mu \mathrm{mol})$ were dissolved in DMSO $(200 \mu \mathrm{L})$ and added to the DTPAethylene diamine solution before stirring overnight at r.t. After rinsing the reaction vial with $\mathrm{H}_{2} \mathrm{O}$ and $\mathrm{CH}_{3} \mathrm{CN}$, the solvents and DIPEA were removed by centrifugal evaporation at $50{ }^{\circ} \mathrm{C}$ and $<0.128 \mathrm{mbar}$ for $5 \mathrm{~h}$. The remaining, slightly yellow oil was used without further purification.

$c[R G D y K]$. This compound was synthesized as previously described. $^{17}$

Phth- $\left(\mathrm{SO}_{3}\right) \mathrm{Cy} 5-\mathrm{COOH}$. The synthesis of the $\mathrm{Cy} 5$ dye was performed based on literature procedures. ${ }^{40}$ In short, IndoleCOOH (1.1 g, $4.0 \mathrm{mmol})$ and $\mathrm{N}-((2 E, 4 E)-4$-(phenylimino) but2-en-1-yl)aniline (1.2 g, $4.4 \mathrm{mmol})$ were dissolved in acetic acid/acetic anhydride $(1: 1,30 \mathrm{~mL})$ and left stirring at $60{ }^{\circ} \mathrm{C}$; progress of the reaction was monitored by absorption spectroscopy. After stirring at $60{ }^{\circ} \mathrm{C}$ overnight, the mixture was heated to $120{ }^{\circ} \mathrm{C}$. The crude product was dissolved in $\mathrm{DMF} / \mathrm{CH}_{2} \mathrm{Cl}_{2}(70 \mathrm{~mL} ; 1: 1)$ after precipitation in diethyl ether $(600 \mathrm{~mL})$. Merrifield resin $(1.2 \mathrm{~g}, 2.0 \mathrm{mmol})$ was suspended in $\mathrm{CH}_{2} \mathrm{Cl}_{2}$ for $5 \mathrm{~min}$ and was then left to bubble in 20\% TFA in $\mathrm{CH}_{2} \mathrm{Cl}_{2}(50.0 \mathrm{~mL})$ for $1 \mathrm{~h}$ and in 20\% DiPEA $(50.0 \mathrm{~mL})$ in $\mathrm{CH}_{2} \mathrm{Cl}_{2}$ for $15 \mathrm{~min}$. The dissolved hemicyanine was then added to the preconditioned resin. After bubbling through $\mathrm{N}_{2}$ for $1 \mathrm{~h}$, the resin was washed with $\mathrm{DMF} / \mathrm{CH}_{2} \mathrm{Cl}_{2}(20 \mathrm{~mL} ; 1: 1)$ thrice. $\left(\mathrm{SO}_{3}\right)$ Indole-AmineC4Phth $(0.44 \mathrm{~g}, 1.0 \mathrm{mmol})$ was dissolved 
in pyridine/acetic anhydride $(40 \mathrm{~mL} ; 3: 1)$ and added to the resin. The resulting reaction mixture was shaken overnight at r.t. Afterward, the liquids were collected and the resin was washed with DMF and/or $\mathrm{CH}_{2} \mathrm{Cl}_{2}$ until the washings were light blue. The crude reaction mixture was concentrated in vacuo and separated by column chromatography $\left(\mathrm{CH}_{2} \mathrm{Cl}_{2}: \mathrm{CH}_{3} \mathrm{OH}\right)$ and then further purified by prep-HPLC, yielding a blue solid after lyophilization $(39.0 \mathrm{mg}, 5 \%)$ with a purity of $99 \% . \mathrm{m} / z[\mathrm{M}+\mathrm{H}]^{+}$ calcd. 750.9, found 751.1. ${ }^{1} \mathrm{H}$ NMR (300 MHz, MeOD) $\delta 8.23$ $(\mathrm{dt}, J=13.0 \mathrm{~Hz}, 2 \mathrm{H}), 7.79-7.88(\mathrm{~m}, 4 \mathrm{H}), 7.23-7.54(\mathrm{~m}, 8 \mathrm{H})$, $6.63(\mathrm{t}, J=12.4 \mathrm{~Hz}, 1 \mathrm{H}), 6.31(\mathrm{~d}, J=13.6 \mathrm{~Hz}, 2 \mathrm{H}), 4.15-4.18$ $(\mathrm{m}, 4 \mathrm{H}), 3.78(\mathrm{~m}, 2 \mathrm{H}), 2.35(\mathrm{t}, J=2.35 \mathrm{~Hz}, 2 \mathrm{H}), 1.82-1.90(\mathrm{~m}$, $6 \mathrm{H}), 1.72-1.75(\mathrm{~m}, 14 \mathrm{H}), 1.53(\mathrm{~m}, 2 \mathrm{H})$ (Figure SI1).

$\mathrm{H}_{2} \mathrm{~N}\left(\mathrm{SO}_{3}\right)-\mathrm{Cy} 5-\mathrm{COOH}$. Phth- $\left(\mathrm{SO}_{3}\right) \mathrm{Cy} 5-\mathrm{COOH}(55.0 \mathrm{mg}$, $73.2 \mu \mathrm{mol}$ ) was dissolved in $\mathrm{CH}_{3} \mathrm{NH}_{2}$ (33 wt \% in ethanol; 25 $\mathrm{mL}$ ). After stirring for $21 \mathrm{~h}$, the reaction appeared to be complete. Residual $\mathrm{CH}_{3} \mathrm{NH}_{2}$ and ethanol were removed in vacuo before dividing into two portions. The crude product was dissolved in $\mathrm{H}_{2} \mathrm{O}(0.1 \% \mathrm{v} / \mathrm{v} \mathrm{TFA})(3 \mathrm{~mL})$ and $\mathrm{CH}_{3} \mathrm{CN}(0.1 \% \mathrm{v} /$ $\mathrm{v}$ TFA) $(1 \mathrm{~mL})$, purified by means of reversed-phase (RP) preparative (prep)-HPLC, and after removal of solvents in vacuo, $\mathrm{H}_{2} \mathrm{~N}\left(\mathrm{SO}_{3}\right)-\mathrm{Cy} 5-\mathrm{COOH}$ was obtained as a blue solid (19.0 mg, 42\%). $\mathrm{m} / z[\mathrm{M}+\mathrm{H}]^{+}$calcd. 620.8 , found $620.6 .{ }^{1} \mathrm{H}$ $\operatorname{NMR}(300 \mathrm{MHz}, \mathrm{DMSO}) \delta 12.01(\mathrm{~s}, 1 \mathrm{H}), 8.37(\mathrm{td}, \mathrm{J}=13.0,5.7$ $\mathrm{Hz}, 2 \mathrm{H}), 7.83$ (d, J = 1.4 Hz, 1H), 7.68-7.64 (m, 1H), 7.64$7.60(\mathrm{~m}, 3 \mathrm{H}), 7.43(\mathrm{~s}, 2 \mathrm{H}), 7.35-7.23(\mathrm{~m}, 3 \mathrm{H}), 6.58(\mathrm{~d}, \mathrm{~J}=12.1$ $\mathrm{Hz}, 1 \mathrm{H}), 6.31(\mathrm{t}, \mathrm{J}=13.9 \mathrm{~Hz}, 2 \mathrm{H}), 4.13(\mathrm{~d}, \mathrm{~J}=6.6 \mathrm{~Hz}, 5 \mathrm{H}), 2.80$ $(\mathrm{s}, 2 \mathrm{H}), 2.20(\mathrm{t}, \mathrm{J}=7.1 \mathrm{~Hz}, 2 \mathrm{H}), 1.71(\mathrm{~s}, 6 \mathrm{H}), 1.68(\mathrm{~s}, 6 \mathrm{H})$, $1.58-1.51(\mathrm{~m}, 4 \mathrm{H}), 1.41-1.34(\mathrm{~m}, 2 \mathrm{H}), 1.23(\mathrm{~s}, 1 \mathrm{H})$ (Figure SI2).

$\mathrm{N}_{3}\left(\mathrm{SO}_{3}\right)-\mathrm{Cy} 5-\mathrm{COOH} . \mathrm{H}_{2} \mathrm{~N}\left(\mathrm{SO}_{3}\right)-\mathrm{Cy} 5-\mathrm{COOH}(43.1 \mathrm{mg}, 66.7$ $\mu \mathrm{mol})$ was dissolved in $\mathrm{CH}_{3} \mathrm{OH}(10 \mathrm{~mL})$ before basifying with $\mathrm{K}_{2} \mathrm{CO}_{3}(180.0 \mu \mathrm{mol})$. $\mathrm{CuSO}_{4}$ (cat., in $\left.\mathrm{H}_{2} \mathrm{O}\right)$ and $1 \mathrm{H}$-imidazole1 -sulfonyl azide hydrochloride $(80.0 \mu \mathrm{mol})$ were added, and the resulting mixture was stirred at r.t. under a $\mathrm{N}_{2}$ atmosphere for 3 h. Then, the solvent was removed in vacuo and the crude product was redissolved in $\mathrm{H}_{2} \mathrm{O}(0.1 \% \mathrm{v} / \mathrm{v}$ TFA) $(3 \mathrm{~mL})$ and $\mathrm{CH}_{3} \mathrm{CN}(0.1 \% \mathrm{v} / \mathrm{v}$ TFA) $(1 \mathrm{~mL})$ and purified by means of $\mathrm{RP}$ prep-HPLC. Solvents were removed in vacuo, yielding a blue solid (28.9 mg, 43\%). $m / z[\mathrm{M}+\mathrm{H}]^{+}$calcd. 646.8, found 646.3. ${ }^{1} \mathrm{H}$ NMR (300 MHz, DMSO- $\left.d_{6}\right) \delta 8.35(\mathrm{td}, J=13.2,4.9 \mathrm{~Hz}$, $2 \mathrm{H}), 7.81$ (d, $J=1.5 \mathrm{~Hz}, 1 \mathrm{H}), 7.69-7.56(\mathrm{~m}, 2 \mathrm{H}), 7.41$ (d, $J=$ $4.1 \mathrm{~Hz}, 2 \mathrm{H}), 7.34(\mathrm{~d}, J=8.3 \mathrm{~Hz}, 1 \mathrm{H}), 7.25(\mathrm{dt}, J=12.4,4.2 \mathrm{~Hz}$, $1 \mathrm{H}), 6.58(\mathrm{t}, J=12.3 \mathrm{~Hz}, 1 \mathrm{H}), 6.32(\mathrm{dd}, J=13.8,9.2 \mathrm{~Hz}, 2 \mathrm{H})$, 4.48 (s, $5 \mathrm{H}), 4.11$ (br s, $J=22.5 \mathrm{~Hz}, 4 \mathrm{H}), 2.20$ (t, $J=7.1 \mathrm{~Hz}$, $2 \mathrm{H}), 1.69(\mathrm{~d}, J=3.2 \mathrm{~Hz}, 14 \mathrm{H}), 1.60-1.47(\mathrm{~m}, 2 \mathrm{H}), 1.46-1.28$ (m, 2H), $1.11(\mathrm{~s}, 2 \mathrm{H})$ (Figure SI3).

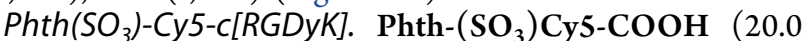
$\mathrm{mg}, 26.7 \mu \mathrm{mol})$, HSPyU $(12.0 \mathrm{mg}, 29.3 \mu \mathrm{mol})$ and DiPEA $(23.0 \mu \mathrm{L}, 133.3 \mu \mathrm{mol})$ were dissolved in DMSO $(400 \mu \mathrm{L}$, dried on $4 \AA$ molecular sieves). After stirring for $30 \mathrm{~min}$ at r.t., $100 \%$ conversion was confirmed by TLC and MALDI-TOF. c[RGDyK] (18.0 mg, $29.3 \mu \mathrm{mol})$ and DiPEA $(9.3 \mu \mathrm{L}, 53.0$ $\mu \mathrm{mol}$ ) were added and the solution was stirred at r.t. for $72 \mathrm{~h}$, whereafter TLC and MALDI-TOF indicated full consumption of $\mathrm{c}$ [RGDyK]. $\mathrm{H}_{2} \mathrm{O}\left(0.1 \% \mathrm{v} / \mathrm{v}\right.$ TFA) $(2.4 \mathrm{~mL})$ and $\mathrm{CH}_{3} \mathrm{CN}$ $(0.1 \% \mathrm{v} / \mathrm{v}$ TFA) $(3 \mathrm{~mL})$ were added, and the compound was purified by RP-HPLC and lyophilized, yielding a blue solid (10.0 $\mathrm{mg}, 28 \%) . \mathrm{m} / z[\mathrm{M}+\mathrm{H}]^{+}$calcd. 1,352.6, found 1,351.8.

$\mathrm{H}_{2} \mathrm{~N}\left(\mathrm{SO}_{3}\right)-\mathrm{Cy} 5-\mathrm{C}[\mathrm{RGDyK}]$. Phth( $\left.\mathrm{SO}_{3}\right)-\mathrm{Cy} 5$-c [RGDyK] (10.0 $\mathrm{mg}, 7.4 \mu \mathrm{mol})$ was dissolved in $\operatorname{DMF}(6 \mathrm{~mL})$, and $\mathrm{CH}_{3} \mathrm{NH}_{2}$ (33\%wt in ethanol) $(20 \mathrm{~mL})$ was added. After stirring at r.t. for $16 \mathrm{~h}$, the reaction was complete according to TLC and MALDI-
TOF. Ethanol and $\mathrm{CH}_{3} \mathrm{NH}_{2}$ were removed in vacuo and the product was precipitated in diethyl ether $(45 \mathrm{~mL})$ and centrifuged. After decanting, the precipitate was washed with ethyl acetate $(45 \mathrm{~mL})$, centrifuged again, and this was repeated twice with diethyl ether $(45 \mathrm{~mL})$. The blue solid was desiccated, redissolved in $\mathrm{H}_{2} \mathrm{O} / \mathrm{CH}_{3} \mathrm{CN}$ ( $4 \mathrm{~mL} ; 1: 1 ; 0.1 \% \mathrm{v} / \mathrm{v}$ TFA), and used without further purification. $m / z[\mathrm{M}+\mathrm{H}]^{+}$calcd. 1,222.5, found 1,222.2.

$\mathrm{N}_{3}\left(\mathrm{SO}_{3}\right)-C y 5-c[R G D y K] . \quad \mathbf{H}_{2} \mathbf{N}\left(\mathrm{SO}_{3}\right)-\mathrm{Cy5}-\mathrm{c}[\mathrm{RGDyK}](2.0$ $\mathrm{mg}, 1.6 \mu \mathrm{mol})$ dissolved in $3: 1 \mathrm{H}_{2} \mathrm{O} / \mathrm{CH}_{3} \mathrm{CN}(2 \mathrm{~mL})$ and imidazole-1-sulfonyl azide hydrochloride $(0.7 \mathrm{mg}, 3.3 \mu \mathrm{mol})$ dissolved in $\mathrm{H}_{2} \mathrm{O} / \mathrm{CH}_{3} \mathrm{CN}(3: 1 ; 500 \mu \mathrm{L}), N$-methylmorpholine $(0.5 \mu \mathrm{L}, 4.3 \mu \mathrm{mol})$, and $\mathrm{CuSO}_{4}$ in $\mathrm{H}_{2} \mathrm{O}$ (cat.) were stirred at r.t. for $5.5 \mathrm{~h}$. Ethyl acetate $(40 \mathrm{~mL})$ and $\mathrm{CH}_{3} \mathrm{OH}(10 \mathrm{~mL})$ were added, leading to precipitation of the crude product. The suspension was centrifuged, decanted, washed twice with diethyl ether, and desiccated. Purification by RP-HPLC followed by lyophilization yielded a blue solid $(490.0 \mu \mathrm{g}, 24 \%) . \mathrm{m} / z[\mathrm{M}+$ $\mathrm{H}]^{+}$calcd. 1,248.5, found 1,248.1.

DTPA.DBCO. $\mathrm{N}_{3}\left(\mathrm{SO}_{3}\right)$-Cy5-c[RGDyK]. $\mathbf{N}_{3}\left(\mathrm{SO}_{3}\right)$-Cy5-c[RGDyK] $(150.0 \mu \mathrm{g}, 120.2 \mathrm{nmol})$ and DTPA-DBCO (294.0 $\mu \mathrm{g}, 480.8 \mathrm{nmol})$ were stirred in DMSO/PBS $/ \mathrm{H}_{2} \mathrm{O}(2: 1: 6 ; 450$ $\mu \mathrm{L})$ for $11.5 \mathrm{~h}$. Then, $\mathrm{H}_{2} \mathrm{O}(0.1 \% \mathrm{v} / \mathrm{v}$ TFA $)(600 \mu \mathrm{L})$ was added and the compound was purified by RP-HPLC yielding a blue solid after lyophilization $(185.0 \mu \mathrm{g}, 78 \%) . m / z[\mathrm{M}+\mathrm{H}]^{+}$calcd. $1,971.2$, found $1,970.1$.

DTPA.BCN. $\mathrm{N}_{3}\left(\mathrm{SO}_{3}\right)-C y 5-c[R G D y K] . \quad \mathbf{N}_{3}\left(\mathrm{SO}_{3}\right)$-Cy5-c[RGDyK] $(150.0 \mu \mathrm{g}, 120.2 \mathrm{nmol})$ and DTPA-BCN (374.0 $\mu \mathrm{g}, 480.8 \mathrm{nmol})$ were stirred in DMSO/PBS $/ \mathrm{H}_{2} \mathrm{O}(2: 1: 7 ; 500$ $\mu \mathrm{L})$ for $11.5 \mathrm{~h}$. Then, $\mathrm{H}_{2} \mathrm{O}(0.1 \% \mathrm{v} / \mathrm{v}$ TFA; $600 \mu \mathrm{L})$ was added and the compound was purified by RP-HPLC (C8) yielding a blue solid after lyophilization $(30.7 \mu \mathrm{g}, 14 \%) . m / z[\mathrm{M}+\mathrm{H}]^{+}$ calcd. 1,860.1, found 1,859.4.

Photophysical Properties. Absorption coefficient $(\varepsilon)$, quantum yield $\left(\Phi_{\mathrm{F}}\right)$, and maximum absorption/emission measurements of $\mathrm{N}_{3}\left(\mathrm{SO}_{3}\right)-\mathrm{Cy5}-\mathrm{COOH}$ and its two conjugates (DT PA.D B C O. N $3\left(\mathrm{SO}_{3}\right)-\mathrm{Cy} 5-\mathrm{c}$ [RGDyK] and DTPA.BCN. $\mathbf{N}_{3}\left(\mathrm{SO}_{3}\right)$-Cy5-c[RGDyK]), serum stability analysis, and serum binding experiments were performed according to the previously described methods. ${ }^{21,22}$ The brightness of the hybrid tracers was based on their respective quantum yield and $\varepsilon_{\text {fluorophore }}$.

Lipophilicity. $\log P_{(\mathrm{o} / \mathrm{w})}$ was calculated according to previously published methods. ${ }^{41}$ In short, to a solution of 0.5-1 MBq of ${ }^{99 \mathrm{~m}} \mathrm{Tc}$ radiolabeled hybrid tracer in $500 \mu \mathrm{L}$ of phosphate-buffered saline (PBS, pH 7.4), $500 \mu \mathrm{L}$ of 1-octanol was added $(n=6)$. Vials were vigorously shaken on a IKA VXR basic Vibrax orbital shaker (IKA-Werke GmbH \& Co. KG, Staufen, Germany) for 3 min and subsequently centrifuged at $6000 \mathrm{rpm}$ for $5 \mathrm{~min}$ in a Fisher Scientific MicroV centrifuge (Fisher Scientific, Hampton) to achieve quantitative phase separation. The activity concentrations in $100 \mu \mathrm{L}$ samples of both the aqueous and organic phases were measured in a PerkinElmer Wizard2 $\gamma$-counter (PerkinElmer, Waltham).

In Vitro Tracer Specificity. A mix of $\alpha_{\mathrm{V}} \beta_{3}$-integrinexpressing Ge $\beta 3$ cells and MDAMB231 X4 cells ${ }^{42}$ was seeded onto coverslips ( $\varnothing 35 \mathrm{~mm}$; MatTek Corporation) and incubated at $37^{\circ} \mathrm{C}$ in $2 \mathrm{~mL}$ of medium for $48 \mathrm{~h}$. One hour prior to imaging, the cells were incubated $\left(37^{\circ} \mathrm{C}\right)$ with DTPA-Lys $\left(\mathbf{C y 5}\left(\mathbf{S O}_{3}\right)\right.$ methyl)-Cys-c[RGDyK], DTPA.DBCO.N ${ }_{3}\left(\mathrm{SO}_{3}\right)$-Cy5-c[RGDyK], or DTPA.BCN.N ${ }_{3}\left(\mathrm{SO}_{3}\right)$-Cy5-c[RGDyK] $(1 \mu \mathrm{M})$. For blocking experiments, $1 \mu \mathrm{M}$ unlabeled $c[\mathrm{RGDyK}]$ was added $1 \mathrm{~h}$ prior to addition of DTPA.DBCO. $\mathrm{N}_{3}\left(\mathrm{SO}_{3}\right)$-Cy5- 
c[RGDyK] or DTPA.BCN.N ${ }_{3}\left(\mathrm{SO}_{3}\right)-\mathrm{Cy5}-\mathrm{c}$ [RGDyK]. Prior to imaging, the cells were washed three times with PBS. Confocal microscopy was performed on viable cells, using an SP8 WLL fluorescence confocal microscope (Leica Microsystems, Wetzlar). For additional reference, the nuclei of the cells were stained with Hoechst 33342 ( $1 \mathrm{mg} / \mathrm{mL}$ stock, Thermo Fisher). Sequential scanning settings were used to visualize the different fluorescent features: Hoechst (nuclear staining; $\lambda_{\mathrm{ex}} 405 \mathrm{~nm}, \lambda_{\mathrm{em}}$ $42-470 \mathrm{~nm})$, intrinsic GFP $\left(\lambda_{\mathrm{ex}} 500 \mathrm{~nm}, \lambda_{\mathrm{em}} 500-550 \mathrm{~nm}\right.$; MDAMB231 X4 only), and Cy5 ( $\left.\lambda_{\text {ex }} 633 \mathrm{~nm}, \lambda_{\text {em }} 650-700 \mathrm{~nm}\right)$. Quantification of cellular uptake was performed as previously described. ${ }^{15}$ In images depicting the Cy5-related signal intensity, regions of interest were placed around the whole cell (minimum of 13 cells per image) using Fuji software, whereafter the pixel intensity per cell could be determined. Unblocked and blocked conditions were evaluated for all three tracers $(n=3$ experiments per condition). For the unblocked conditions, the percentage of fluorescence uptake (intensity per cell) was set at $100 \%$. The percentage fluorescence uptake after blocking was determined relative to the unblocked condition.

Receptor Affinity. The affinity $\left(K_{\mathrm{D}}\right)$ of the tracers for $\mathrm{Ge} \beta 3$ cells was determined by saturation binding experiments. To this end, $3 \times 10^{5}$ cells were incubated for $1 \mathrm{~h}$ at $4{ }^{\circ} \mathrm{C}$ with different concentrations of either DTPA.DBCO. $\mathrm{N}_{3}\left(\mathrm{SO}_{3}\right)$-Cy5-c[RGDyK] or DTPA.BCN.N ${ }_{3}\left(\mathrm{SO}_{3}\right)-\mathrm{Cy} 5-\mathrm{c}[\mathrm{RGDyK}]$ ranging from 0 to $1500 \mathrm{nM}$. To accomplish this, $\mathrm{Ge} \beta 3$ cells were trypsinized, pelleted ( $4 \mathrm{~min}, 1200 \mathrm{rpm}, 4^{\circ} \mathrm{C}$ ), and resuspended in Dulbecco's modified Eagle's medium (DMEM; enriched with $5 \%$ fetal bovine serum and $1 \%$ penicillin/strepcillin $(1: 1 \mathrm{v} / \mathrm{v}))$ to obtain a concentration of $6 \times 10^{6}$ cells $/ \mathrm{mL}$. Subsequently, $50 \mu \mathrm{L}$ of the cell suspension $\left(3 \times 10^{5}\right.$ cells $)$ was added to $50 \mu \mathrm{L}$ of the tracer in cold DMEM $(0-3000 \mathrm{nM})$. After $1 \mathrm{~h}$ incubation at 4 ${ }^{\circ} \mathrm{C}$, the samples were washed three times with $0.1 \%$ fetal calf serum in cold PBS by pelleting ( $4 \mathrm{~min}, 1200 \mathrm{rpm}, 4^{\circ} \mathrm{C}$ ) and subsequently resuspended in $150 \mu \mathrm{L}$ of $0.1 \%$ fetal calf serum in cold PBS. The samples were then measured by flow cytometry using an LSR-II after excitation at $633 \mathrm{~nm}$ and collecting the signal in the APC-A channel. All experiments were performed in triplicate.

Normalized geometric means were fitted with equations in the GraphPad Prism 7 software. The $K_{\mathrm{D}}$ values were calculated using the "Binding-Saturation, One site-Total" nonlinear regression equation (eq 1), with the background value set at 0 .

$$
\log \mathrm{IC}_{50}=\log \left(10^{\log K_{\mathrm{D}}}\left(1+\frac{[\mathrm{ref}]}{K_{\mathrm{D}, \text { ref }}}\right)\right)
$$

where $y=$ normalized fluorescence, $B_{\max }=$ maximum specific binding in the units of the $y$-axis, $x=$ concentration of the hybrid labeled tracer, $K_{\mathrm{D}}=$ equilibrium dissociation constant of the hybrid labeled tracer in nanomolar.

Radiolabeling. For $\log \mathrm{P}$ experiments, $66 \mu \mathrm{L}$ of $10 \mu \mathrm{M}$ Tin(II)chloride dihydrate in sodium acetate buffer $(250 \mathrm{mM}$, $\mathrm{pH} 4.0$ ) and $6 \mathrm{MBq}$ of ${ }^{99 \mathrm{~m}} \mathrm{Tc}$ in $7-11 \mu \mathrm{L}$ saline were added to 1 nmol compound dissolved in a $\mathrm{NH}_{4} \mathrm{OAc}$ buffer $(250 \mathrm{mM}, \mathrm{pH}$ 5.5). After shaking at room temperature for $5 \mathrm{~min}$, the radiochemical purity was determined to be $>90 \%$ using iTLC with PBS as eluent.

For biodistribution experiments, $4 \mathrm{nmol}$ of either DTPA.DBCO. $\mathrm{N}_{3}\left(\mathrm{SO}_{3}\right)$-Cy5-c[RGDyK] or DTPA.BCN.N $\mathrm{N}_{3}\left(\mathrm{SO}_{3}\right)-\mathrm{Cy} 5-$ c $\left[\right.$ RGDyK] was dissolved in a $\mathrm{NH}_{4} \mathrm{OAc}$ buffer $(0.25 \mathrm{M}$; $\mathrm{pH}=$ 5.5) and mixed with $12.2 \mu \mathrm{L}$ of an ${ }^{111} \mathrm{InCl}_{3}$ solution in $0.05 \mathrm{M}$ $\mathrm{HCl}(0.33 \mathrm{MBq} / \mu \mathrm{L}$, Mallinckrodt Medical, Petten, The
Netherlands). The mixtures were shaken for $1 \mathrm{~h}$ at r.t. After addition of $\mathrm{HCl}(0.05 \mathrm{M} ; 232 \mu \mathrm{L})$, the mixtures were supplemented with isotonic PBS to obtain a volume of 600 $\mu \mathrm{L}$, and $150 \mu \mathrm{L}(1 \mathrm{nmol})$ per mouse was then injected.

For combined imaging and biodistribution experiments, 2 nmol of each compound, dissolved in a $\mathrm{NH}_{4} \mathrm{OAc}$ buffer $(0.25$ $\mathrm{M} ; \mathrm{pH}=5.5$ ), was mixed with $121.9 \mu \mathrm{L}$ of an ${ }^{111} \mathrm{InCl}_{3}$ solution in $0.05 \mathrm{M} \mathrm{HCl}(0.33 \mathrm{MBq} / \mu \mathrm{L}$, Mallinckrodt Medical, Petten, The Netherlands). The mixtures were shaken for $1 \mathrm{~h}$ at r.t., whereafter the mixtures were supplemented with isotonic PBS to obtain an injection volume of $300 \mu \mathrm{L}$.

In Vivo Imaging and Biodistribution. The 4T1 tumor model was generated in $\mathrm{BALB} / \mathrm{c}$ nude mice, as previously described. ${ }^{28}$ The animal studies were approved by the institutional Animal Ethics Committee of the Leiden University Medical Center.

Imaging and biodistribution were performed $24 \mathrm{~h}$ after intravenous tracer $(1 \mathrm{nmol})$ administration $(n=6$ animals for each tracer; $n=4$ biodistribution only, 2 SPECT imaging/ biodistribution). SPECT imaging was performed as previously described. ${ }^{17,21}$ Maximum intensity projection images were generated and analyzed using Matlab software (MathWorks, Natick, MA) according to previously described methods. ${ }^{21}$ Hereafter, fluorescence imaging was performed in vivo and ex vivo using an IVIS Spectrum imaging system (Caliper Life Science, Hopkinton, MA). Images were acquired at $\lambda_{\mathrm{ex}}=640$ $\mathrm{nm}, \lambda_{\mathrm{em}}=680 \mathrm{~nm}$, and image analysis was performed using the Living Image software from Xenogen v 3.2 (Caliper LS). In vivo fluorescence images were used to provide a direct link to the in vivo SPECT images.

For assessment of the biodistribution of the tracers, the mice were sacrificed and organs and tissues were surgically excised. The amount of radioactivity in the tissues was counted using a $\gamma$ counter (2470 automatic $\gamma$ counter, PerkinElmer, $245 \mathrm{keV}, 60$ $\mathrm{s})$, and the percentage of the injected dose per gram of tissue (\% ID/g) was calculated according to previously described methods. ${ }^{17}$

Statistical Analysis. Analytical data were expressed as mean and standard deviation as calculated using Microsoft Excel and GraphPad Prism 7 software. In this study, significance of two mean values was calculated by the unpaired $t$-test or one-way ANOVA unless noted otherwise. The level of significance was set at $p<0.05$.

\section{ASSOCIATED CONTENT}

\section{S Supporting Information}

The Supporting Information is available free of charge on the ACS Publications website at DOI: 10.1021/acsomega.9b01484.

${ }^{1} \mathrm{H}$ NMR spectra of Phth-( $\left.\mathrm{SO}_{3}\right) \mathrm{Cy5}-\mathrm{COOH}, \mathrm{H}_{2} \mathrm{~N}$ ( $\mathrm{SO}_{3}$ ) Cy5-COOH and $\mathrm{N}_{3}-\left(\mathrm{SO}_{3}\right) \mathrm{Cy5}-\mathrm{COOH}$; mass spectra of DTPA-Lys ( $\mathrm{Cy} 5\left(\mathrm{SO}_{3}\right)$ methyl)-Cys-c[RGDyK], DTPA.DBCO. $\mathrm{N}_{3}\left(\mathrm{SO}_{3}\right)-\mathrm{Cy} 5-\mathrm{c}[\mathrm{RGDyK}$, and DTPA.BCN.N ${ }_{3}\left(\mathrm{SO}_{3}\right)-\mathrm{Cy} 5-\mathrm{c}[\mathrm{RGDyK}]$; and analytical HPLC images of DTPA.DBCO. $\mathrm{N}_{3}\left(\mathrm{SO}_{3}\right)$-Cy5-c[RGDyK] and DTPA.BCN.N $\mathrm{N}_{3}\left(\mathrm{SO}_{3}\right)-\mathrm{Cy} 5-\mathrm{c}[\mathrm{RGDyK}]$ (PDF)

\section{AUTHOR INFORMATION}

\section{Corresponding Author}

*E-mail: F.W.B.van_Leeuwen@lumc.nl.

ORCID $\odot$

Mick M. Welling: 0000-0002-2249-5601 
Tessa Buckle: 0000-0003-2980-6895

Fijs W. B. van Leeuwen: 0000-0002-6844-4025

\section{Notes}

The authors declare no competing financial interest.

\section{ACKNOWLEDGMENTS}

Sven I. van Leeuwen is gratefully acknowledged for his work on the illustrations. The authors thank Nikolas Duszenko for thoroughly proofreading and editing the manuscript. This research was funded by an NWO-TTW-VICI grant (TTW 16141) and the 2015-2016 Post-Doctoral Molecular Imaging Scholar Program Grant granted by the Society of Nuclear Medicine and Molecular Imaging (SNMMI) and the Education and Research Foundation for Nuclear Medicine and Molecular Imaging.

\section{ABBREVIATIONS}

(DTPA), 4, diethylenetriaminepentaacetic acid

(DMF), 17, dimethylformamide

(HSPyU), 16, dipyrrolidino( $N$-succinimidyloxy)carbenium hexafluorophosphate

(HPLC), 15, high-performance liquid chromatography

(MALDI-TOF), 15, matrix-assisted laser desorption/ionization time-of-flight

$(\varepsilon), 7$, molar absorbance coefficient

(DiPEA), 16, N,N-diisopropylethylamine

(NMR), 16, nuclear magnetic resonance

(prep), 19, preparative

$\left(\Phi_{\mathrm{F}}\right), 7$, quantum yield

(RP), 19, reversed-phase

(SPECT) imaging, 11, single-photon emission computed tomography

(TFA), 16, trifluoroacetic acid

\section{REFERENCES}

(1) Lee, J. A.; Wiggins, J. M.; Rice, L. P.; Siemann, D. W. Abstract 5211: In vivo fluorescence and spectral microscopy of the effects of aerobic exercise on tumor oxygenation and perfusion in breast cancer. Cancer Res. 2015, 75, No. 5211.

(2) Bakkum, T.; van Leeuwen, T.; Sarris, A. J. C.; van Elsland, D. M.; Poulcharidis, D.; Overkleeft, H. S.; van Kasteren, S. I. Quantification of Bioorthogonal Stability in Immune Phagocytes Using Flow Cytometry Reveals Rapid Degradation of Strained Alkynes. ACS Chem. Biol. 2018, 13, 1173-1179.

(3) Burggraaf, J.; Kamerling, I. M.; Gordon, P. B.; Schrier, L.; de Kam, M. L.; Kales, A. J.; Bendiksen, R.; Indrevoll, B.; Bjerke, R. M.; Moestue, S. A.; Yazdanfar, S.; Langers, A. M.; Swaerd-Nordmo, M.; Torheim, G.; Warren, M. V.; Morreau, H.; Voorneveld, P. W.; Buckle, T.; van Leeuwen, F. W.; Odegardstuen, L. I.; Dalsgaard, G. T.; Healey, A.; Hardwick, J. C. Detection of colorectal polyps in humans using an intravenously administered fluorescent peptide targeted against c-Met. Nat. Med. 2015, 21, 955-961.

(4) Sturm, M. B.; Joshi, B. P.; Lu, S.; Piraka, C.; Khondee, S.; Elmunzer, B. J.; Kwon, R. S.; Beer, D. G.; Appelman, H. D.; Turgeon, D. K.; Wang, T. D. Targeted imaging of esophageal neoplasia with a fluorescently labeled peptide: first-in-human results. Sci. Transl. Med. 2013, 5, No. 184ra61.

(5) van Leeuwen, F. W.; Hardwick, J. C.; van Erkel, A. R. Luminescence-based Imaging Approaches in the Field of Interventional Molecular Imaging. Radiology 2015, 276, 12-29.

(6) Rosenthal, E. L.; Warram, J. M.; Bland, K. I.; Zinn, K. R. The status of contemporary image-guided modalities in oncologic surgery. Ann. Surg. 2015, 261, 46-55.

(7) Chin, P. T.; Welling, M. M.; Meskers, S. C.; Valdes Olmos, R. A.; Tanke, H.; van Leeuwen, F. W. Optical imaging as an expansion of nuclear medicine: Cerenkov-based luminescence vs fluorescence-based luminescence. Eur. J. Nucl. Med. Mol. Imaging 2013, 40, 1283-1291.

(8) Bugby, S. L.; Lees, J. E.; Perkins, A. C. Hybrid intraoperative imaging techniques in radioguided surgery: present clinical applications and future outlook. Clin. Transl. imaging 2017, 5, 323-341.

(9) KleinJan, G. H.; van Werkhoven, E.; van den Berg, N. S.; Karakullukcu, M. B.; Zijlmans, H.; van der Hage, J. A.; van de Wiel, B. A.; Buckle, T.; Klop, W. M. C.; Horenblas, S.; Valdes Olmos, R. A.; van der Poel, H. G.; van Leeuwen, F. W. B. The best of both worlds: a hybrid approach for optimal pre- and intraoperative identification of sentinel lymph nodes. Eur. J. Nucl. Med. Mol. Imaging 2018, 45, 1915-1925.

(10) van Leeuwen, F. W.; Valdes-Olmos, R.; Buckle, T.; Vidal-Sicart, $S$. Hybrid surgical guidance based on the integration of radionuclear and optical technologies. Br. J. Radiol. 2016, 89, No. 20150797.

(11) Garanger, E.; Aikawa, E.; Reynolds, F.; Weissleder, R.; Josephson, L. Simplified syntheses of complex multifunctional nanomaterials. Chem. Commun. 2008, 39, 4792-4794.

(12) Guo, Y.; Yuan, H.; Rice, W. L.; Kumar, A. T.; Goergen, C. J.; Jokivarsi, K.; Josephson, L. The PEG-fluorochrome shielding approach for targeted probe design. J. Am. Chem. Soc. 2012, 134, 19338-19341.

(13) Agarwal, P.; Bertozzi, C. R. Site-specific antibody-drug conjugates: the nexus of bioorthogonal chemistry, protein engineering, and drug development. Bioconjugate Chem. 2015, 26, 176-192.

(14) Pan, H.; Li, W. J.; Yao, X. J.; Wu, Y. Y.; Liu, L. L.; He, H. M.; Zhang, R. L.; Ma, Y. F.; Cai, L. T. In Situ Bioorthogonal Metabolic Labeling for Fluorescence Imaging of Virus Infection In Vivo. Small 2017, 13, No. 1604036.

(15) van der Wal, S.; de Korne, C. M.; Sand, L. G. L.; van Willigen, D. M.; Hogendoorn, P. C. W.; Szuhai, K.; van Leeuwen, F. W. B.; Buckle, T. Bioorthogonally Applicable Fluorescence Deactivation Strategy for Receptor Kinetics Study and Theranostic Pretargeting Approaches. ChemBioChem 2018, 19, 1758-1765.

(16) Ahn, S. H.; Boros, E. Nuclear and Optical Bimodal Imaging Probes Using Sequential Assembly: A Perspective. Cancer Biother. Radiopharm. 2018, 33, 308-315.

(17) Bunschoten, A.; van Willigen, D. M.; Buckle, T.; van den Berg, N. S.; Welling, M. M.; Spa, S. J.; Wester, H. J.; van Leeuwen, F. W. Tailoring Fluorescent Dyes To Optimize a Hybrid RGD-Tracer. Bioconjugate Chem. 2016, 27, 1253-1258.

(18) Haubner, R.; Kuhnast, B.; Mang, C.; Weber, W. A.; Kessler, H.; Wester, H. J.; Schwaiger, M. [18F]Galacto-RGD: synthesis, radiolabeling, metabolic stability, and radiation dose estimates. Bioconjugate Chem. 2004, 15, 61-69.

(19) Adulnirath, A.; Chung, S. W.; Park, J.; Hwang, S. R.; Kim, J. Y.; Yang, V. C.; Kim, S. Y.; Moon, H. T.; Byun, Y. Cyclic RGDykconjugated LMWH-taurocholate derivative as a targeting angiogenesis inhibitor. J. Controlled Release 2012, 164, 8-16.

(20) Kuil, J.; Buckle, T.; Oldenburg, J.; Yuan, H.; Borowsky, A. D.; Josephson, L.; van Leeuwen, F. W. Hybrid peptide dendrimers for imaging of chemokine receptor 4 (CXCR4) expression. Mol. Pharm. 2011, 8, 2444-2453.

(21) Buckle, T.; van Willigen, D. M.; Spa, S. J.; Hensbergen, A. W.; van der Wal, S.; de Korne, C. M.; Welling, M. M.; van der Poel, H. G.; Hardwick, J. C. H.; van Leeuwen, F. W. B. Tracers for FluorescenceGuided Surgery: How Elongation of the Polymethine Chain in Cyanine Dyes Alters the Pharmacokinetics of a Dual-Modality c[RGDyK] Tracer. J. Nucl. Med. 2018, 59, 986-992.

(22) Spa, S. J.; Hensbergen, A. W.; van der Wal, S.; Kuil, J.; van Leeuwen, F. W. B. The influence of systematic structure alterations on the photophysical properties and conjugation characteristics of asymmetric cyanine 5 dyes. Dyes Pigm. 2018, 152, 19-28.

(23) van Leeuwen, F. W. B.; Cornelissen, B.; Caobelli, F.; Evangelista, L.; Rbah-Vidal, L.; Del Vecchio, S.; Xavier, C.; Barbet, J.; de Jong, M. Generation of fluorescently labeled tracers - which features influence the translational potential? EJNMMI Radiopharm. Chem. 2017, DOI: $10.1186 /$ s41181-017-0034-8.

(24) Goddard-Borger, E. D.; Stick, R. V. An efficient, inexpensive, and shelf-stable diazotransfer reagent: imidazole-1-sulfonyl azide hydrochloride. Org. Lett. 2007, 9, 3797-3800. 
(25) Levitus, M.; Ranjit, S. Cyanine dyes in biophysical research: the photophysics of polymethine fluorescent dyes in biomolecular environments. Q. Rev. Biophys. 2011, 44, 123-151.

(26) Tredwell, C. J.; Keary, C. M. Picosecond Time Resolved Fluorescence Lifetimes of the Polymethine and Related Dyes. Chem. Phys. 1979, 43, 307-316.

(27) KleinJan, G. H.; Bunschoten, A.; van den Berg, N. S.; Olmos, R. A.; Klop, W. M.; Horenblas, S.; van der Poel, H. G.; Wester, H. J.; van Leeuwen, F. W. Fluorescence guided surgery and tracer-dose, fact or fiction? Eur. J. Nucl. Med. Mol. Imaging 2016, 43, 1857-1867.

(28) Bunschoten, A.; Buckle, T.; Visser, N. L.; Kuil, J.; Yuan, H.; Josephson, L.; Vahrmeijer, A. L.; van Leeuwen, F. W. Multimodal interventional molecular imaging of tumor margins and distant metastases by targeting alphavbeta3 integrin. ChemBioChem 2012, 13, 1039-1045.

(29) van der Wal, S.; Kuil, J.; Valentijn, A. R. P. M.; van Leeuwen, F. W. B. Synthesis and systematic evaluation of symmetric sulfonated centrally C C bonded cyanine near-infrared dyes for protein labelling. Dyes Pigm. 2016, 132, 7-19.

(30) Pozzi, A.; Zent, R. Integrins in kidney disease. J. Am. Soc. Nephrol. 2013, 24, 1034-1039.

(31) Kreidberg, J. A.; Symons, J. M. Integrins in kidney development, function, and disease. Am. J. Physiol. Renal Physiol. 2000, 279, F233F242.

(32) Warn, P. A.; Sharp, A.; Parmar, A.; Majithiya, J.; Denning, D. W.; Hope, W. W. Pharmacokinetics and pharmacodynamics of a novel triazole, isavuconazole: mathematical modeling, importance of tissue concentrations, and impact of immune status on antifungal effect. Antimicrob. Agents Chemother. 2009, 53, 3453-3461.

(33) Margoliash, E.; Novogrodsky, A.; Schejter, A. Irreversible reaction of 3-amino-1:2:4-triazole and related inhibitors with the protein of catalase. Biochem. J. 1960, 74, 339-348.

(34) Hoshino, M. Effect of 3-amino-1,2,4-triazole on the experimental production of liver cancer. Nature 1960, 186, 174-175.

(35) Oliveira, B. L.; Guo, Z.; Bernardes, G. J. L. Inverse electron demand Diels-Alder reactions in chemical biology. Chem. Soc. Rev. 2017, 46, 4895-4950.

(36) Meyer, J. P.; Houghton, J. L.; Kozlowski, P.; Abdel-Atti, D.; Reiner, T.; Pillarsetty, N. V.; Scholz, W. W.; Zeglis, B. M.; Lewis, J. S. 18F-Based Pretargeted PET Imaging Based on Bioorthogonal DielsAlder Click Chemistry. Bioconjugate Chem. 2016, 27, 298-301.

(37) Canovas, C.; Moreau, M.; Vrigneaud, J. M.; Bellaye, P. S.; Collin, B.; Denat, F.; Goncalves, V. Modular Assembly of Multimodal Imaging Agents through an Inverse Electron Demand Diels-Alder Reaction. Bioconjugate Chem. 2019, 30, 888-897.

(38) Mujumdar, R. B.; Ernst, L. A.; Mujumdar, S. R.; Lewis, C. J.; Waggoner, A. S. Cyanine dye labeling reagents: sulfoindocyanine succinimidyl esters. Bioconjugate Chem. 1993, 4, 105-111.

(39) Gu, J.; Anumala, U. R.; Heyny-von Haussen, R.; Holzer, J.; Goetschy-Meyer, V.; Mall, G.; Hilger, I.; Czech, C.; Schmidt, B. Design, synthesis and biological evaluation of trimethine cyanine dyes as fluorescent probes for the detection of tau fibrils in Alzheimer's disease brain and olfactory epithelium. ChemMedChem 2013, 8, 891-897.

(40) Lopalco, M.; Koini, E. N.; Cho, J. K.; Bradley, M. Catch and release microwave mediated synthesis of cyanine dyes. Org. Biomol. Chem. 2009, 7, 856-859.

(41) Weineisen, M.; Simecek, J.; Schottelius, M.; Schwaiger, M.; Wester, H.-J. Synthesis and preclinical evaluation of DOTAGAconjugated PSMA ligands for functional imaging and endoradiotherapy of prostate cancer. EJNMMI Res. 2014, 4, 63.

(42) Luker, K.; Gupta, M.; Luker, G. Bioluminescent CXCL12 fusion protein for cellular studies of CXCR4 and CXCR7. BioTechniques 2009, 47, 625-632. 